\title{
Analysis of streamflow characteristics over Northeastern Canada in a changing climate
}

\author{
O. Huziy $\cdot$ L. Sushama $\cdot$ M. N. Khaliq $\cdot$ \\ R. Laprise $\cdot$ B. Lehner $\cdot$ R. Roy
}

Received: 31 January 2012/ Accepted: 21 May 2012 / Published online: 9 June 2012

(C) The Author(s) 2012. This article is published with open access at Springerlink.com

\begin{abstract}
An analysis of streamflow characteristics (i.e. mean annual and seasonal flows and extreme high and low flows) in current and future climates for 21 watersheds of north-east Canada covering mainly the province of Quebec is presented in this article. For the analysis, streamflows are derived from a 10-member ensemble of Canadian Regional Climate Model (CRCM) simulations, driven by the Canadian Global Climate Model simulations, of which five correspond to current 1970-1999 period, while the other five correspond to future 2041-2070 period. For developing projected changes of streamflow characteristics from current to future periods, two different approaches are used: one based on the concept of ensemble averaging while the other approach is based on merged samples of current and similarly future simulations following multiple
\end{abstract}

O. Huziy $(\square) \cdot$ L. Sushama · M. N. Khaliq ·

R. Laprise · R. Roy

Centre ESCER (Étude et Simulation du Climat à l'Échelle

Régionale), University of Quebec at Montreal, 201 Ave.

President-Kennedy, Montreal, QC H3C 3P8, Canada

e-mail: guziy.sasha@gmail.com

\section{N. Khaliq}

Global Institute for Water Security, University of Saskatchewan,

11 Innovation Boulevard, Saskatoon, SK S7N 3H5, Canada

B. Lehner

Department of Geography, McGill University, Burnside Hall, Room 612, 805 Sherbrooke Street West, Montreal, QC H3A 2K6, Canada

R. Roy

Ouranos, 550 Sherbrooke Street West, 19th Floor, West Tower, Montreal, QC H3A 1B9, Canada

R. Roy

Hydro-Quebec, 1800 Lionel-Boulet Boulevard, Varennes, QC, Canada comparison tests. Verification of the CRCM simulated streamflow characteristics for the 1970-1999 period suggests that the model simulated mean hydrographs and high flow characteristics compare well with those observed, while the model tends to underestimate low flow extremes. Results of projected changes to mean annual streamflow suggest statistically significant increases nearly all over the study domain, while those for seasonal streamflow show increases/decreases depending on the season. Two- and 5 -year return levels of 15-day low flows are projected to increase significantly over most part of the study domain, though the changes are small in absolute terms. Based on the ensemble averaging approach, changes to 10- and 30-year return levels of high flows are not generally found significant. However, when a similar analysis is performed using longer samples, significant increases to high flow return levels are found mainly for northernmost watersheds. This study highlights the need for longer samples, particularly for extreme events in the development of robust projections.

Keywords Climate change - Extreme flows - Regional climate modelling $\cdot$ Statistical analysis

\section{Introduction}

Reliable information about various streamflow characteristics in a changing climate is critical for planning of adaptation measures, particularly for energy and agriculture sectors. According to the Fourth Assessment Report (AR4) of the Intergovernmental Panel on Climate Change (IPCC) (2007), global mean precipitation and evaporation rates are projected to increase in future climate, or in other words an intensification of the global hydrological cycle is 
to be expected in future warmer climate. However, there will be important regional differences in changes to precipitation and evaporation. Held and Soden (2006), based on their analysis of the coupled climate models that participated in the AR4, suggests that the poleward vapour transport and the pattern of evapotranspiration minus precipitation will increase proportionally to the lower-tropospheric vapour if the lower-tropospheric relative humidity and flow is assumed unchanged. In other words, the current wet (dry) regions, i.e. regions where precipitation (evaporation) exceeds evaporation (precipitation), will become wetter (drier) in a future climate. Northeastern Canada, the region considered in this study, has an excess of precipitation over evaporation, with mean annual precipitation of the order of $800 \mathrm{~mm}$ according to the 1980-2010 normals based on the Global Precipitation Climatology Centre (Rudolf et al. 2010), and average annual evaporation of the order of $200 \mathrm{~mm}$ according to the 1980-2010 normals calculated using the European Centre for Medium-Range Weather Forecasts (ECMWF)'s ERA interim reanalysis data (Berrisford et al. 2009). According to the Global Climate Models (GCMs) participating in AR4 (IPCC 2007), the mean annual precipitation rate for this region is projected to increase by $0.4-0.5 \mathrm{~mm} /$ day, while mean annual evaporation and runoff increase by $0.1-0.2$ and $0.1-0.3 \mathrm{~mm} /$ day, respectively, in the future 2080-2099 period with respect to the 1980-1999 period. This northeastern part of Canada with its large number of hydroelectric power generation stations plays a very important role in the economy of the provinces located in the region, particularly the province of Quebec. Therefore, information on projected changes to various streamflow characteristics and associated uncertainties would be beneficial for better management of these mega-projects, including the "Plan Nord" recently initiated by the Government of Quebec (http://plannord.gouv.qc.ca).

The conventional approach to study projected changes to streamflow is based on hydrological models driven by climate model outputs for various scenarios. Few studies so far have looked at streamflow directly from climate models: GCMs and Regional Climate Models (RCMs). RCMs and GCMs, with their complete closed water budget including both the atmospheric and land surface branches, are ideal tools to understand better the linkages and feedback between climate and hydrological systems, and to evaluate the impact of climate change on streamflows. RCMs offer higher spatial resolution than GCMs, allowing for greater topographic complexity and finer-scale atmospheric dynamics to be simulated and thereby representing a more adequate tool for generating the information required for regional impact studies. In a number of recent studies, RCMs have been used to study projected changes to various components of the hydrological cycle including
Table 1 Description of 21 watersheds used in the study

\begin{tabular}{lllr}
\hline No. & Name of the watershed & Abbreviation & Area $\left(\mathrm{km}^{2}\right)$ \\
\hline 1 & Arnaud & ARN & 26,872 \\
2 & Feuilles & FEU & 42,068 \\
3 & Mélèzes & MEL & 40,624 \\
4 & Caniapiscau & CAN & 37,566 \\
5 & Caniapiscau (Pyrite) & PYR & 48,431 \\
6 & Grande rivière de la Baleine & GRB & 34,314 \\
7 & Baleine & BAL & 29,896 \\
8 & George & GEO & 24,159 \\
9 & Churchil Falls & CHU & 69,632 \\
10 & La Grande Rivière & LGR & 140,374 \\
11 & Natashquan & NAT & 15,468 \\
12 & Romaine & ROM & 13,212 \\
13 & Moisie & MOI & 19,101 \\
14 & Manicouagan & MAN & 29,343 \\
15 & Rupert & RUP & 41,115 \\
16 & Bell & BEL & 22,238 \\
17 & Saint Maurice & STM & 42,843 \\
18 & Ottawa & RDO & 143,241 \\
19 & Saguenay & SAG & 72,678 \\
20 & Bersimis-Outardes-Manic & BOM & 87,511 \\
21 & Waswanipi & WAS & 31,691 \\
\hline & & &
\end{tabular}

streamflows (Jha et al. 2004; Wood et al. 2004; Sushama et al. 2006; Kay et al. 2006a, b; Graham et al. 2007a, b; Dadson et al. 2011; Poitras et al. 2011).

In this study, climate change impacts on selected streamflow characteristics for 21 northeast Canadian watersheds, located mainly in the Quebec province and some parts of the adjoining Ontario and Newfoundland and Labrador provinces of Canada, are considered. A tenmember ensemble of the Canadian RCM (CRCM), of which five correspond to current 1970-1999 period and the other five correspond to future 2041-2070 period, driven by five different members of a Canadian GCM (CGCM) initial condition ensemble is used for this purpose. RCM simulations in general are associated with several uncertainties including structural uncertainties associated with regional model formulation, uncertainties associated with the lateral boundary conditions from the driving GCM, emission scenarios, as well as the RCM's own internal variability. de-Elia et al. (2008) quantified some of these uncertainties using larger CRCM ensembles. Though it is very desirable to assess the various sources of uncertainties in streamflow projections as in Arnell (2011) and Kay et al. (2009), given the nature of the ensemble used in this study, it is not possible to address or quantify all uncertainties since the simulations considered here have been performed with the same model and configuration for one SRES (Special Report on Emissions Scenario) scenario. 
However, it can be used to quantify uncertainty associated with the natural variability of the driving GCM and the internal variability of the RCM combined.

For the northeast Canadian region considered in this work, no study has so far addressed projected changes to streamflow characteristics for all the 21 watersheds in a systematic way as presented in this study. Some studies focusing on individual watersheds in this northeast region of Canada such as Dibike and Coulibaly (2007), Quilbé et al. (2008), Minville et al. (2008, 2009), among others, based on hydrological models driven by temperature and precipitation data from climate models, are available. Recently Frigon et al. (2010) studied projected changes to mean annual runoff for the same region considered in this study and suggested increases in runoff in future climate for the northern part of the region. The main value of this work is in the detailed statistical analysis of mean annual, seasonal and extreme (low/high) flows and their associated uncertainties and timings of extreme flows, topics that were not covered by earlier studies for this area in the context of a changing climate.

The article is organized as follows: description of the CRCM and simulations are presented in Sect. 2 and methodology is presented in Sect. 3. Evaluation of the CRCM simulated streamflow and assessment of projected changes to selected but important streamflow characteristics using two approaches are presented in Sect. 4 followed by conclusions in Sect. 5 .

\section{Model and experiments}

The streamflows considered in this study are simulated by the fourth generation of the CRCM (de-Elia and Cote 2010). The CRCM is a limited-area nested model based on the fully elastic non-hydrostatic Euler equations, solved with a semi-implicit and semi-Lagrangian scheme. Vertical resolution is variable with a Gal-Chen scaled-height terrain following coordinate (29 levels, with model top at $29 \mathrm{~km}$ ) (Gal-Chen and Somerville 1975). The CRCM lateral boundary conditions are provided through a one-way nesting method inspired by Davies (1976) and refined by Yakimiw and Robert (1990). The subgrid-scale parameterization package is mostly based on the Canadian GCM Version III (CGCM3.1), except for the moist convective adjustment scheme that follows Bechtold-Kain-Fritsch's parameterization (Bechtold et al. 2001). The land surface scheme is the Canadian LAnd Surface Scheme (CLASS), version 2.7 (Verseghy 1991, 1996). This version of CLASS uses three soil layers, $0.1,0.25$ and $3.75 \mathrm{~m}$ thick, corresponding approximately to the depth influenced by the diurnal cycle, the rooting zone and the annual variations of temperature, respectively. CLASS includes prognostic equations for energy and water conservation for the three soil layers and a thermally and hydrologically distinct snow pack where applicable (treated as a fourth variable-depth layer). The thermal budget is performed over the three soil layers, but the hydrological budget is done only for layers above the bedrock. Vegetation canopy in CLASS is treated explicitly with properties based on four vegetation types: coniferous trees, deciduous trees, crops and grass. Vegetation canopy can intercept rain and snow precipitation and has its own energy and water treatment with prognostic variables for canopy temperature, water storage and mass. CLASS adopts a pseudo-mosaic approach and divides each grid-cell into a maximum of four sub-areas: bare soil, vegetation, snow over bare soil and snow with vegetation. The energy and water budget equations are first solved for each sub-area separately and then averaged over the gridcell.

As already mentioned, a 10-member CRCM ensemble is considered in this study. Of the 10 members, five correspond to current 1970-1999 period while the other five are the matching pairs of simulations for the future 2041-2070 period. Five different members of a CGCM initial condition ensemble were used to drive the five CRCM current and future simulations. It should be noted that the future climate simulations correspond to IPCC's SRES A2 scenario (high population, low economy and low technology) and current climate simulations correspond to the twentieth-century climate (20C3M) scenario. The above current and future CRCM simulations will be referred to as $\mathrm{C} 1-\mathrm{C} 5$ and $\mathrm{F} 1-\mathrm{F} 5$, respectively. In addition, another CRCM simulation driven by the ECMWF's Re-Analysis (ERA40; Uppala et al. 2005) is also considered. This simulation will be referred to as "control simulation' hereafter. As suggested by IPCC (2001), the study of RCM simulations nested by analysis of observations or so-called 'perfect' boundary conditions such as ERA40 can reveal RCM 'performance errors'. Therefore, the streamflows from the control simulation are compared to those observed to assess the CRCM's performance. The inset of Fig. 1 shows the CRCM simulation domain, which consists of a $200 \times 192$ points grid covering whole of North America and adjoining oceans, with a horizontal grid-point spacing of $45 \mathrm{~km}$. It should be noted that the current study focuses only on the 21 watersheds located in the north-east part of the simulation domain (Fig. 1).

Streamflow is generated from CRCM simulated runoff using a modified version of the routing model WATROUTE (Soulis et al. 2000). The routing scheme solves the water balance equation at each grid-cell, and relates the water storage to outflow from the grid-cell, using Manning's equation. The modified scheme includes a groundwater reservoir, which is modelled as a linear reservoir as 
(a)

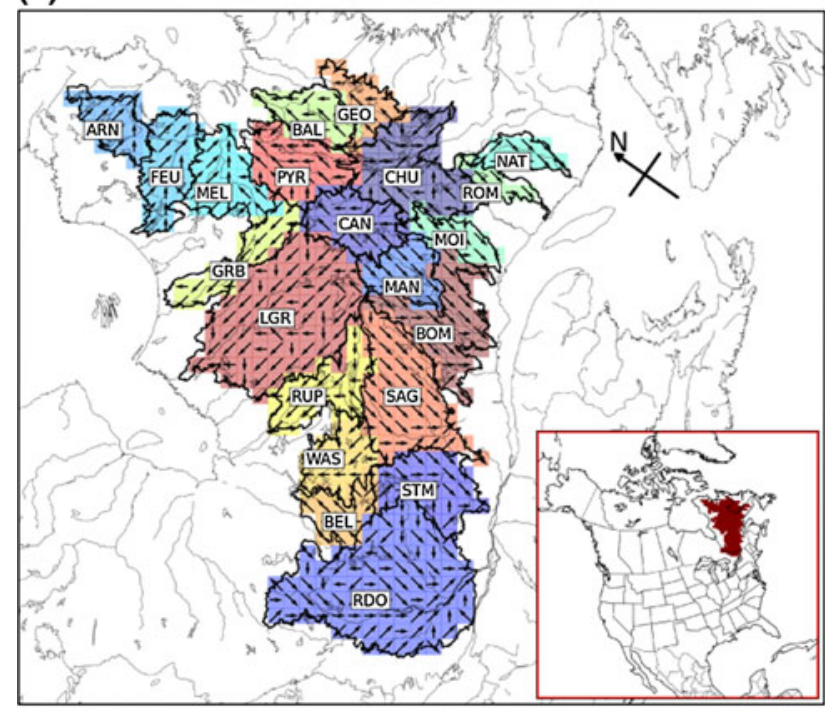

(b)

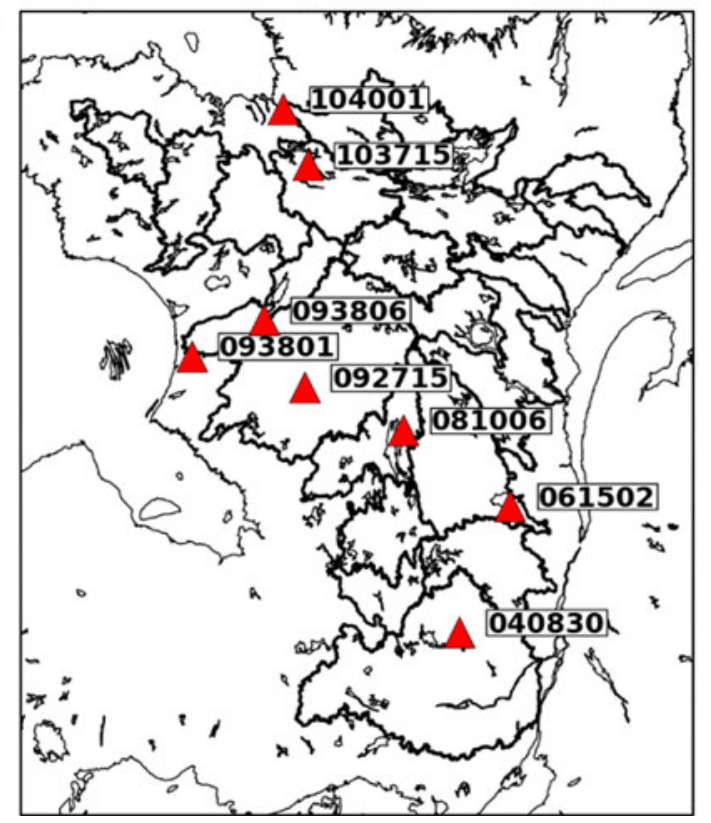

Fig. 1 a Study domain with its 21 watersheds along with the flow directions. Watersheds are marked using their abbreviated names (Table 1). Simulation domain of the CRCM is shown in the inset. b Location of the gauging stations (red triangles) used in the evaluation of CRCM simulated streamflow characteristics. Station identification numbers assigned by CEHQ are also shown

proposed in Lucas-Picher et al. (2003) and Sushama et al. (2004). Flow directions, channel lengths and slopes required by the routing scheme were derived from the HydroSHEDS database (Lehner et al. 2008), available at 30 -second resolution on a latitude-longitude grid. This data was up-scaled and projected to the model's grid and resolution. The up-scaling algorithm is based on the one developed by Döll and Lehner (2002). The flow directions thus derived are also shown in Fig. 1.

\section{Methodology}

Verification of CRCM-simulated mean hydrological regime and characteristics of extreme flow events, i.e. timing and return levels of selected return periods, and their projected changes in future climate are considered in this study. For verification purposes, model-simulated streamflow characteristics from the control simulation are compared to those observed, derived from the daily streamflow dataset from CEHQ (Centre d'expertise hydrique du Québec; http://www.cehq.gouv.qc.ca/) at selected gauging stations. The location of the gauging stations considered in the study is shown in Fig. 1b. The duration of the data available at these gauging stations, within the period of interest, i.e. 1970-1999, varies from 10 to 20 years. Nash-Sutcliffe (ns) index (Nash and Sutcliffe 1970) and correlation coefficient $(r)$ (Walpole and Myers 1985) are used to compare the observed and modelled daily mean hydrographs at these stations. In addition, biases in the timing and magnitude of peak flows are explored and connections established with those in temperature and snow water equivalent (SWE) where applicable.

The Generalized Extreme Value (GEV) distribution is used to compute return levels of extreme (high and low) flow events. A high (low) flow event is defined as the maximum (minimum) 1-day (15-day) flow occurring over the March to July (January to May) period. Ten- and 30 -year return periods are considered for high flows, while 2- and 5-year return periods are considered for low flows. The choice of smaller return periods for low flows is based on the fact that a hydrological drought of 2-year return period is catastrophic enough to have an adverse impact not only on the hydropower sector, but also on the ecosystem, particularly the aquatic life (Smakhtin 2001). The cumulative distribution function of the GEV distribution is given by:

$$
\begin{aligned}
G(z) & =\operatorname{Probability}(Z \leq z) \\
& =\exp \left\{-[1+\xi(z-\mu) / \sigma]^{-1 / \xi}\right\},
\end{aligned}
$$

where the extreme flow $z$ is such that $1+\xi(z-\mu) / \sigma>0$, and $\mu, \sigma$ and $\xi$ are respectively the location, scale and shape parameters. Full range of properties and some common applications of the GEV distribution are described in Coles (2001). There are several methods that are often used for parameter estimation of this distribution: Probability Weighted Moments (PWM) (Hosking et al. 1985), L-moments (Hosking 1990), Maximum Likelihood (ML), Generalized Maximum Likelihood (GML) (Martins and Stedinger 2000) and mixed methods (Ailliot et al. 2011). One of the advantages of the GML and ML is that the fitted data automatically belongs to the domain of definition of the obtained probability density function, which is not 
guaranteed by other methods. However, the ML method performs poorly for small samples (Stedinger et al. 1993).

In order to estimate parameters $\mu, \sigma$ and $\xi$ of the GEV distribution, the GML approach proposed by Martins and Stedinger (2000), but using a uniform prior distribution for the shape parameter $\xi$ as in Ailliot et al. (2011) is used. Knowing the parameters of the GEV distribution, low-flow return level for a given return period $T$ (in years) is estimated using the relationship $G(z) T=1$, as

$z(T, \mu, \sigma, \xi)=(\sigma / \xi)\left[(\ln T)^{-\xi}-1\right]+\mu$

For high flows, a return level is estimated using the relationship $[1-G(z)] T=1$, as

$z(T, \mu, \sigma, \xi)=(\sigma / \xi)\left[\left(\ln \frac{T}{T-1}\right)^{-\xi}-1\right]+\mu$

Projected changes to mean annual, seasonal and extreme flows are assessed for the 2041-2070 period with respect to the current 1970-1999 period. This is achieved by comparing statistics of interest derived from the F1-F5 simulations with the corresponding statistics derived from the $\mathrm{C} 1-\mathrm{C} 5$ simulations. Projected changes to seasonal streamflows are linked with projected changes in seasonal temperature, precipitation and SWE, where possible. In the assessment of projected changes to mean, seasonal and extreme flows, two approaches are adopted. In the first approach, projected changes based on each pair of the five CRCM current and future simulations are estimated, which are then averaged to obtain the ensemble-averaged projected change. In the second approach, based on the statistical evidence provided by the multiple comparison tests, i.e. the Kruskal-Wallis test (Walpole and Myers 1985) and ranksum test (Walpole and Myers 1985) combined with the False Discovery Rate (FDR) approach of Benjamini and Hochberg (1995), the five simulations for the current climate are merged to create a longer sample for each grid-cell. The same procedure is followed for the future climate. The projected changes are then assessed from the merged current and future period longer samples. Similar approaches have been used in May (2008) to assess projected changes to extreme precipitation events and characteristics of wet and dry spells over Europe. The advantage of this second approach over the first one is reduced uncertainty associated with extreme flow return levels due to larger sample size. Uncertainties due to smaller sample sizes could be substantial for extreme flow return levels (Stedinger et al. 1993).

Statistical significance of projected changes to mean annual and seasonal flows and selected return levels of extreme (high and low) flows are assessed using the nonparametric vector bootstrap resampling method (Efron and Tibshirani 1993; GREHYS 1996; Khaliq et al. 2009) to estimate standard errors and assuming normality of these statistics to develop confidence intervals (Hall et al. 2004; Mladjic et al. 2011), as discussed below. For a given sample of flows at a grid-cell, the $95 \%$ confidence interval for a statistic (i.e. mean annual and seasonal flow or a return level) is calculated as: $\mathrm{R} 0 \pm 1.96 \mathrm{SE}$, where $\mathrm{R} 0$ is the sample statistic and SE is the standard error of the statistic estimated using 1,000 bootstrap resamples. Such confidence intervals for selected return levels and mean annual and seasonal flows are calculated for each gridpoint for both future and current climates. The statistical significance of the difference between the future and current period values is assessed using these confidence intervals. The change (positive/negative) is considered significant if, for a given case, these confidence intervals do not overlap. The Student's $t$ test (Walpole and Myers 1985) is also used to test the statistical significance of the difference between the current and future period mean annual and seasonal flows. For the case of ensemble averaged statistics, ensemble averaged standard errors are used to develop confidence intervals.

Confidence in the CRCM projections is assessed on the basis of the spread of projected changes obtained with the five pairs of current/future simulations, represented here by the coefficient of variation $(\mathrm{CV})$, defined as the ratio of the standard deviation to the ensemble-mean change based on the five pairs of CRCM simulations. Small (large) values of $\mathrm{CV}$ are suggestive of high (low) confidence level in the CRCM projections. Given the nature of the CRCM ensemble, the spread in the CRCM projected changes computed as discussed above will reflect the part of the uncertainty associated with the natural variability of the CGCM3.1 and CRCM's own internal variability.

\section{Results}

\subsection{Model verification}

The observed and modelled hydrographs (mean daily streamflows) are compared at selected stations in Fig. 2. Modelled hydrographs are derived from the CRCM's control simulation. For some basins, important differences can be noted both in the magnitude and timing of peak flows, which are reflected in the $n s$ and $r$ values shown in Fig. 2. These differences can be partly explained by the biases associated with the temperature and precipitation and therefore in the SWE in the CRCM control simulation (Fig. 3). The biases in the winter (DJF) SWE are estimated by comparing climatologic winter SWE from CRCM's control simulation with that from the gridded North American SWE data from Brown et al. (2003). The observational dataset (Brown et al. 2003) was produced by applying the snow depth analysis scheme 
Fig. 2 Comparison of observed and modelled hydrographs (mean daily streamflows). The length of the observed record varies from 10 to 20 years within the 1970-1999 period. The values of the NashSutcliffe (ns) index and correlation coefficient $(r)$ based on mean daily streamflow comparisons, station identification number and longitude-latitude values of station location are also shown
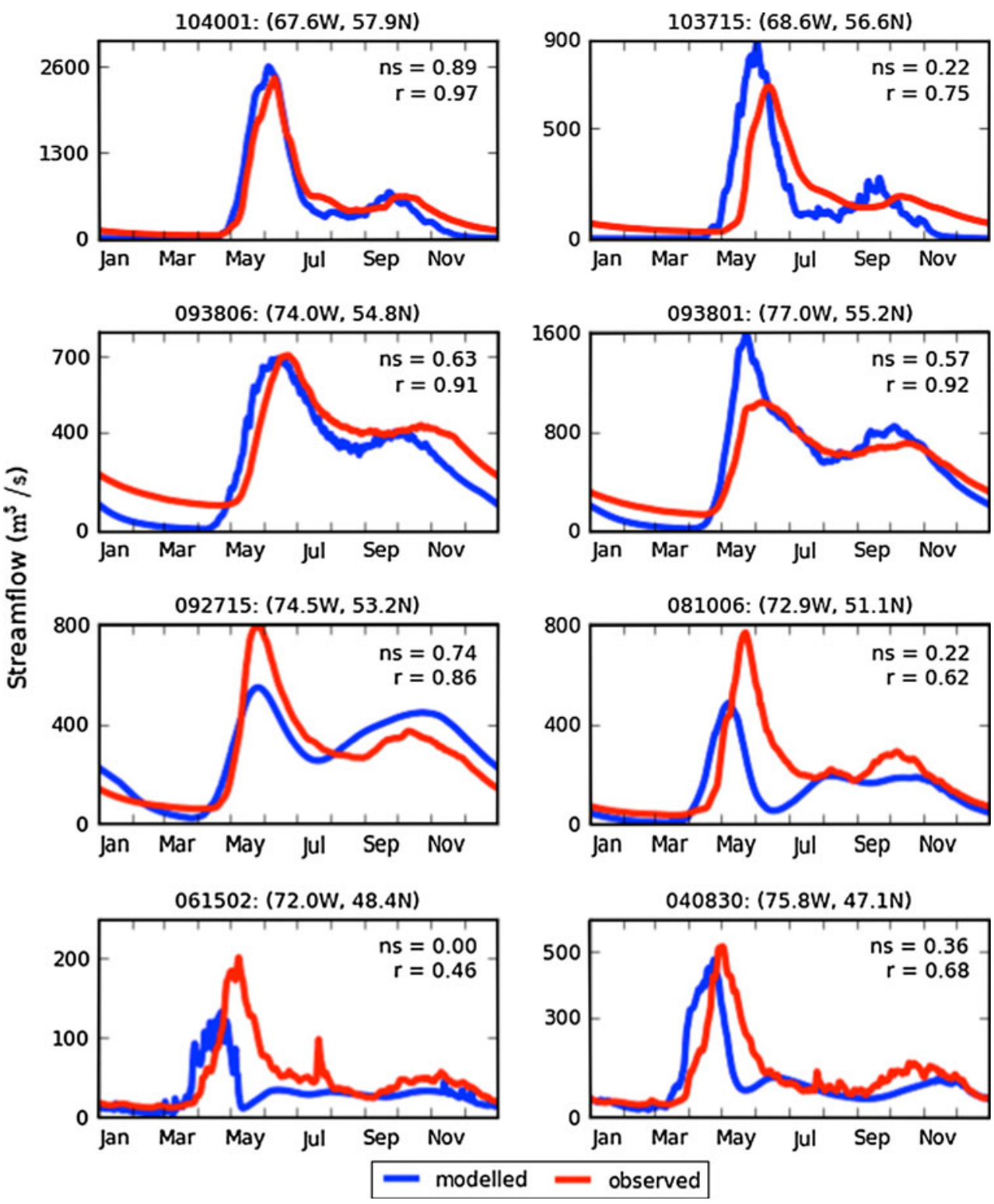

developed by Brasnett (1999) to generate a $0.3^{\circ}$ latitude/ longitude grid of daily and monthly mean snow depth and corresponding estimated water equivalent for North America. This observational dataset was produced for the 1979-1997 period and therefore Fig. 3a presents validation of climatologic SWE for the 1979-1997 DJF period, common to both simulated and observed datasets. The spring (MAM) temperature biases presented in Fig. 3b are estimated by comparing 1971-1999 MAM temperature climatology from CRCM control simulation with that from the gridded Climatic Research Unit (CRU2; Mitchell and Jones 2005) analyzed data.

For the northernmost gauging stations 103715 and 093801, magnitude of peak flows is overestimated, while they are reasonably well simulated for stations 104001 and
093806. Careful examination of the biases in SWE (Fig. 3a; see Fig. 1a for flow directions) suggests that the overestimation of peak magnitudes for the two stations is associated with the positive biases in SWE for the region upstream of the stations. However, for the gauging stations located in the central to southern watersheds, i.e. 092715 , 081006 and 061502 , an underestimation of peak magnitudes is noted. This is due to the underestimation of SWE for the regions upstream of these stations, which contribute to the streamflows at the stations (Fig. 3a). In general, for all basins, the simulated peaks occur earlier than observed, and is believed to be due to the positive temperature bias (Fig. 3b) during spring (MAM). It should be noted though that the model underestimates temperature for the other seasons (figure not shown). 
(a) Winter (DJF)

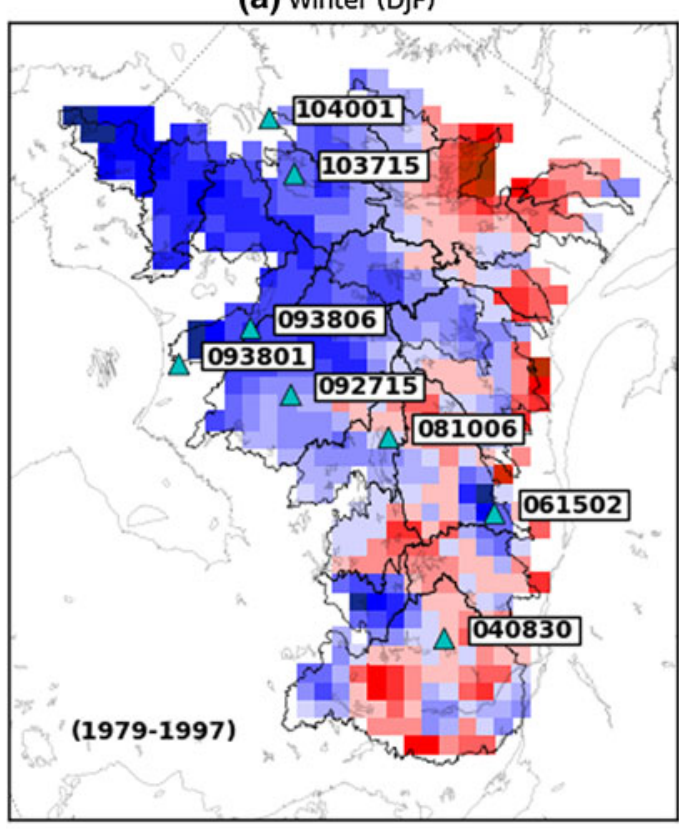

$\mathrm{mm}$
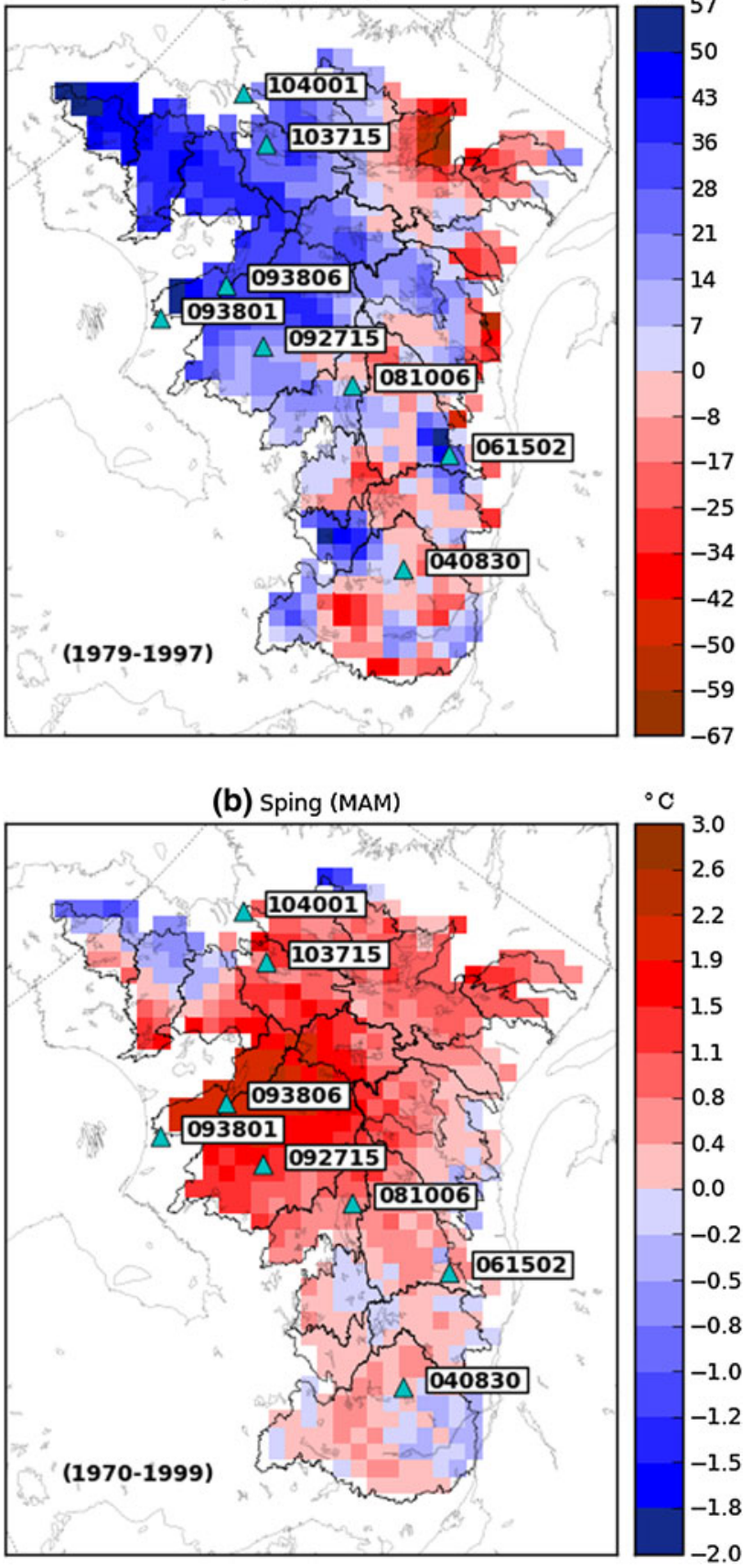

Fig. 3 Biases in the a mean winter (DJF) snow water equivalent (in $\mathrm{mm}$ ) and $\mathbf{b}$ mean spring (MAM) 2-m temperature (in ${ }^{\circ} \mathrm{C}$ )

Characteristics of low and high flows are also validated by performing a comparison between modelled return levels and those obtained from observations. As reported in Sushama et al. (2006) and Khaliq et al. (2008), low-flow events can occur in late winter or early spring due to prolonged cold periods, or can occur in late fall mainly associated with increased evapotranspiration. The low-flow events considered in this study are for the January-May period, i.e. those associated with longer cold periods, while the high-flow events considered are for the March-July snowmelt dominated period.

Comparison of observed and modelled return levels (Fig. 4) at the same gauging stations shown in Fig. 1 suggests that the model is able to capture the high flow magnitudes reasonably well. However, the errors associated with the low flows are large, particularly for the northern watersheds. This is primarily due to the coarse resolution of the soil dataset and therefore values of depth to bedrock used in the model and the drainage formulation used in the model. For the northernmost watersheds, depth to bedrock is mostly $0.1 \mathrm{~m}$, i.e. only the top $0.1 \mathrm{~m}$ of the soil column is hydrologically active. Besides, according to the drainage formulation used in CLASS, the depth to bedrock must be deeper than $0.35 \mathrm{~m}$ to have any drainage. Therefore in winter months, for these regions with depth to bedrock in the $0.1-0.35 \mathrm{~m}$ range, drainage is zero in the model and therefore the ground water contribution is very much reduced. A new formulation for drainage is currently being implemented in the new version of CRCM, which may help eliminate some of these discrepancies. The underestimation of low flows, particularly for the northern watersheds, can also be partly attributed to the overestimation of snow and the underestimation of total precipitation at the end of fall, which both tend to decrease the winter flow. In the absence of an alternative, we will henceforth assume that the errors in low flows related to the soil dataset and drainage formulation will remain the same in the future climate, and therefore will not affect the climate-change signal.

\subsection{Projected changes based on ensemble averaging approach}

\subsubsection{Mean annual and seasonal flows}

Ensemble averaged projected changes to the mean annual streamflow for the future 2041-2070 period, with respect to the current 1970-1999 period, are shown in Fig. 5a. Statistical significance of the projected changes, at the $5 \%$ significance level, is assessed using the vector bootstrapbased test discussed in the methodology section. The mean annual flow is projected to increase from current to future and the changes are statistically significant for majority of the watersheds, except the RDO, BEL, STM, southern parts of WAS and SAG, and some parts of NAT, ROM, MOI and BOM watersheds. The magnitude of percentage changes to mean annual flows is larger for northern compared to other watersheds.

The ensemble-averaged projected changes to the seasonal (DJF, MAM, JJA, and SON) flows are shown in 
Fig. 4 Scatter plots of selected observed and modelled a high and $\mathbf{b}$ low flow return levels (in $\mathrm{m}^{3} / \mathrm{s}$ )
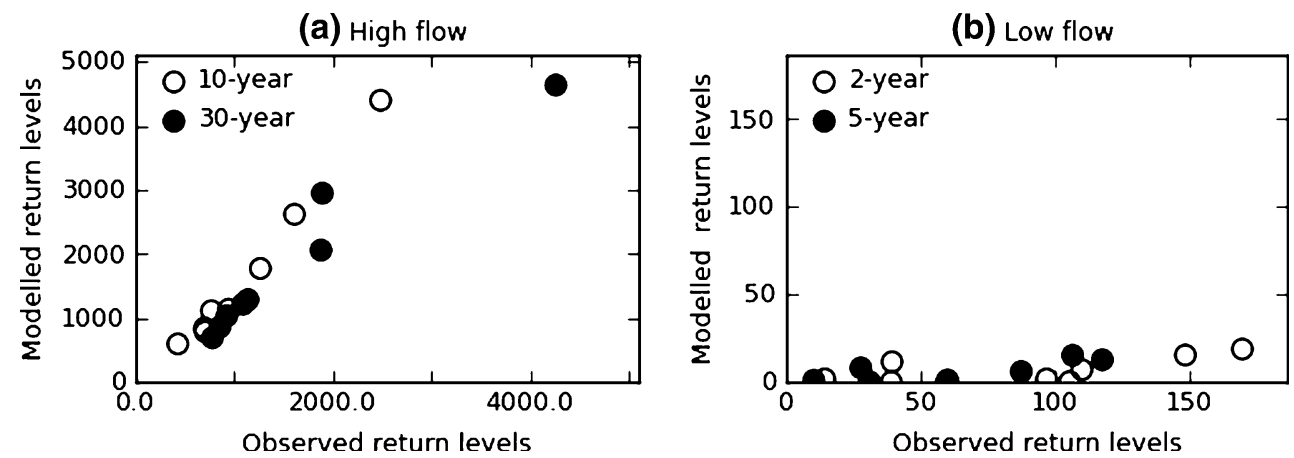

Figs. 5b-e. From the seasonal plots, the changes for the northern part of the domain are consistently positive throughout the year, except for some non-significant decreases in summer (JJA). For the southern regions, however, increases can be noted during the winter (DJF) and spring (MAM) seasons, while decreasing streamflows are projected for the summer (JJA) and fall (SON) seasons, resulting in the non-significant or smaller projected changes to mean annual streamflow for this region. Furthermore, $t$ test is also applied to individual pairs of current and future period simulations and the $p$ values of the $t$ test also suggest significant changes for most of the studied watersheds during winter, while for the other seasons, regions with non-significant changes were noted (figure not shown), as is the case for the ensemble averaged changes shown in Fig. 5b-e.

The above noted projected changes in seasonal streamflows are associated with changes in temperature and precipitation and therefore SWE, which are shown in Figs. 6 and 7, for various seasons. The vector bootstrap-based test, discussed earlier, has been used to assess significance of projected changes, at $5 \%$ significance level, for temperature, precipitation and SWE shown in Figs. 6 and 7. Figure 6 suggests that the ensemble averaged projected increases in temperature are significant for all watersheds, for all seasons. Projected changes to temperature are maximum for winter, and are generally in the $3.5-6{ }^{\circ} \mathrm{C}$, for the entire studied region. The ensemble averaged projected changes to precipitation (Fig. 7a-d) suggest significant increases almost everywhere for winter and spring, while the changes are not significant for the southern watersheds during summer and fall.

The significant increase in winter streamflows (Fig. 5b) discussed earlier can be partly attributed to the significant increase in temperature during fall and winter, which delays the freezing of soil, thus increasing drainage in the central to southern watersheds where the depth to bedrock is deeper than $0.35 \mathrm{~m}$. In addition, significant increase in precipitation and increased fraction of winter precipitation falling as rain instead of snow, due to warmer temperatures, also contribute to increased streamflows during the winter period. The spring flows for all studied watersheds, as already discussed, are related to snowmelt. As can be seen from Fig. 7e, majority of the watersheds show no significant changes to SWE during DJF. However, the increased temperatures during MAM (Fig. 6b) cause earlier snowmelt, which is responsible for the noted significant increase in spring streamflows.

During summer, though precipitation increases are significant for the northern regions (Fig. 7c), streamflows show no significant changes due to increased evaporation associated with warmer temperatures in summer (Fig. 6c). The northern regions show some increases in streamflows during fall, which could be attributed to the increased precipitation and temperature in future climate; it should be noted that since the soil in the northernmost regions, in current climate, start freezing up in late fall, the warmer temperatures in future climate delay this, leading to increased streamflows.

\subsubsection{High- and low-flow extremes}

Prior to looking at projected changes to return levels of high and low flows, it is useful to see if the selected periods (i.e. March-July for high flows and January-May for low flows) would be suitable for future climate as well. Figures 8 and 9 show ensemble averaged annual frequency of occurrence of high and low flow events, respectively, for current and future climates, for northern, central and southern watersheds. The frequencies are normalized by the number of years (30 in the present case) and the number of grid cells in a given watershed. High flows from snowmelt mostly occur during the March to July period as expected (Fig. 8) - high flows associated with the majority of the southern watersheds occur as early as April, while for northern watersheds they occur somewhere between May and June. From the insets of Fig. 8, one can see that the high flow events occur earlier in future climate for most of the watersheds, with the high flows still concentrated over the March-July period. Therefore, the choice of the 
Fig. 5 Ensemble averaged projected changes to mean $\mathbf{a}$ annual and $\mathbf{b}-\mathbf{e}$ seasonal streamflow. Grid cells where the changes are not significant at the $5 \%$ significance level are masked in grey
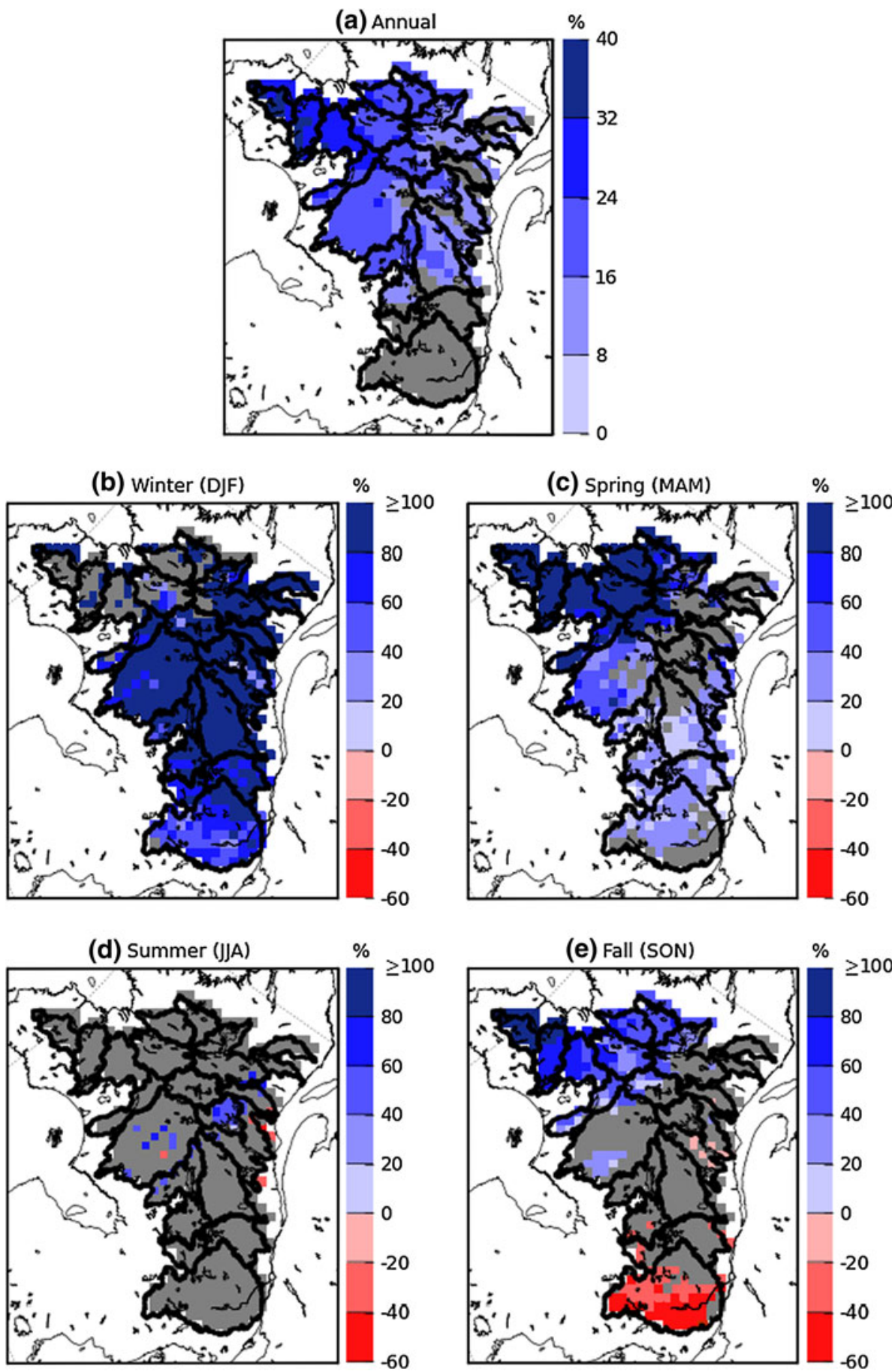

March-July period to study high-flows is satisfactory for both current and future climates.

From Fig. 9, it can be seen that the low-flow events, in both current and future climates, caused by prolonged winter periods, occur during the January-May period, with low flows occurring earlier within this period for southern and central watersheds and towards the middle of the period for northern watersheds. Majority of the low-flow events occur at the end of winter or at the beginning of the spring season. For some southern watersheds, low-flow events are projected to occur more in fall in future climate compared to current climate. For example for RDO watershed (index 18), most of the low-flow events in future climate are projected to occur during the SeptemberOctober period. BEL and STM watersheds also show similar trends, though less pronounced. In future climate, 
Fig. 6 Ensemble averaged projected changes to mean a-d seasonal 2-m temperature. Grid cells where the changes are not significant at the $5 \%$ significance level are masked in grey
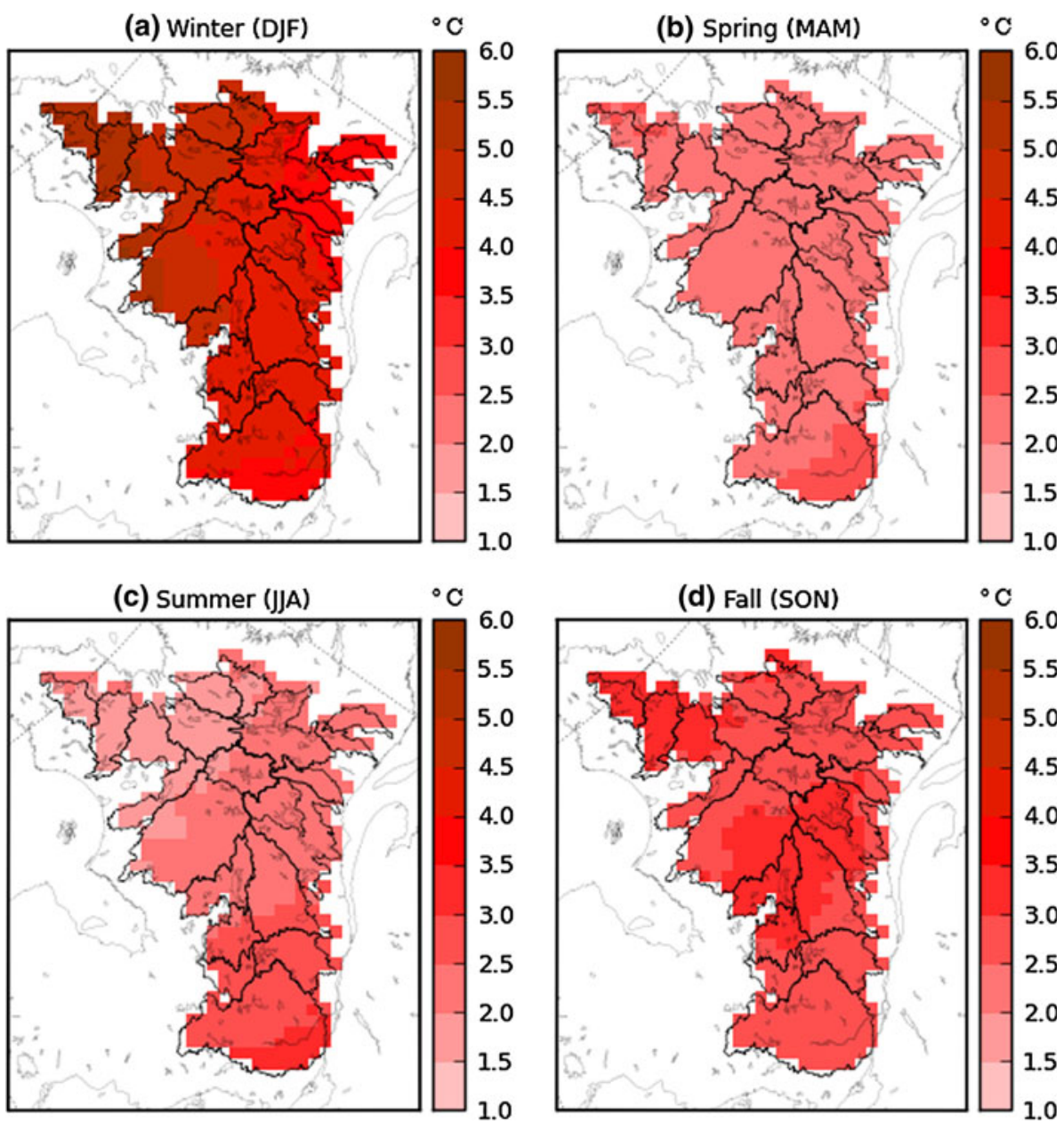

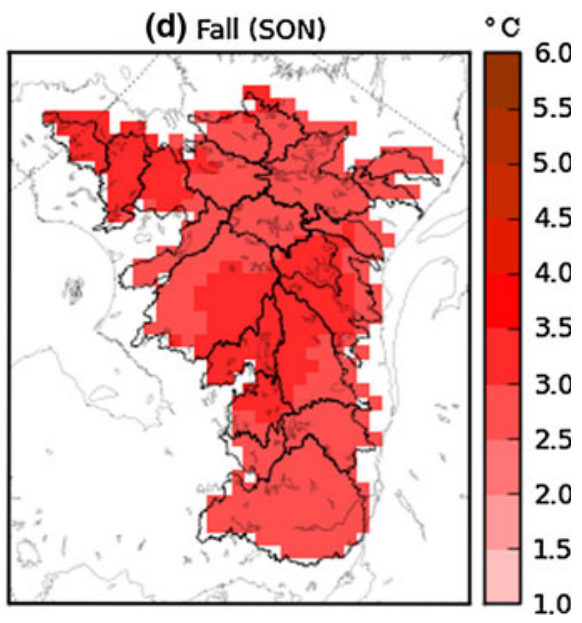

early occurrence of low flows in the January-May period is clearly seen from the insets of Fig. 9. Despite this shift, the January-May period is still satisfactory for the study of low flows.

Projected changes to 10- and 30-year return levels of high flows, for the five pairs of current and future simulations are shown in Figs. 10 and 11, respectively. The results for three of the five pairs suggest increases over most part of the domain for both 10- and 30-year return levels, with the remaining two suggesting primarily negative changes mixed with positive changes at scattered grid cells. Important differences are seen between the projections based on the five pairs of CRCM simulations. An investigation of the spread among the five current and five future simulations based on the $\mathrm{CV}$ measure indicate that, the spread among the future members is large compared to the current members, particularly for central and southern watersheds. A preliminary investigation suggests that this could partly be due to the increased differences between the sea surface temperatures (SSTs) and sea ice cover (SIC) in the five future CRCM simulations compared to the five current climate simulations, particularly in the Hudson Bay region, which is located to the west of the study domain. An in-depth analysis is required to identify other contributing factors and is not attempted here as it is outside the scope of this article. Though ensemble-averaged projected changes to 10- and 30-year return levels are positive for most parts, significant changes are found only for a few grid cells located mainly in the northern watersheds (Figs. 10f, 11f). This is due to the low level of agreement between the results of individual members in the sign of change for high-flow return levels.

Changes to 2- and 5-year low-flow return levels (Figs. 12,13) exhibit strong agreement across members, showing increases all over the study domain (there is only a single grid-cell in the RDO watershed where a negative change is found-Figs. 12a, 13a). Though the relative changes to low flows are high, the absolute changes are indeed small. Overall, there are only slight differences for the southern and northern parts of the domain. This agreement is expected, since the low flow is influenced by the averaged effect of spring, summer and autumn precipitation events and thereby shows less variability, whereas high flows depend on spring precipitation and 
Fig. 7 Ensemble averaged projected changes to mean a-d seasonal precipitation (in $\mathrm{mm} /$ day), and e winter (DJF) SWE (in mm). Grid cells where the changes are not significant at the $5 \%$ significance level are masked in grey
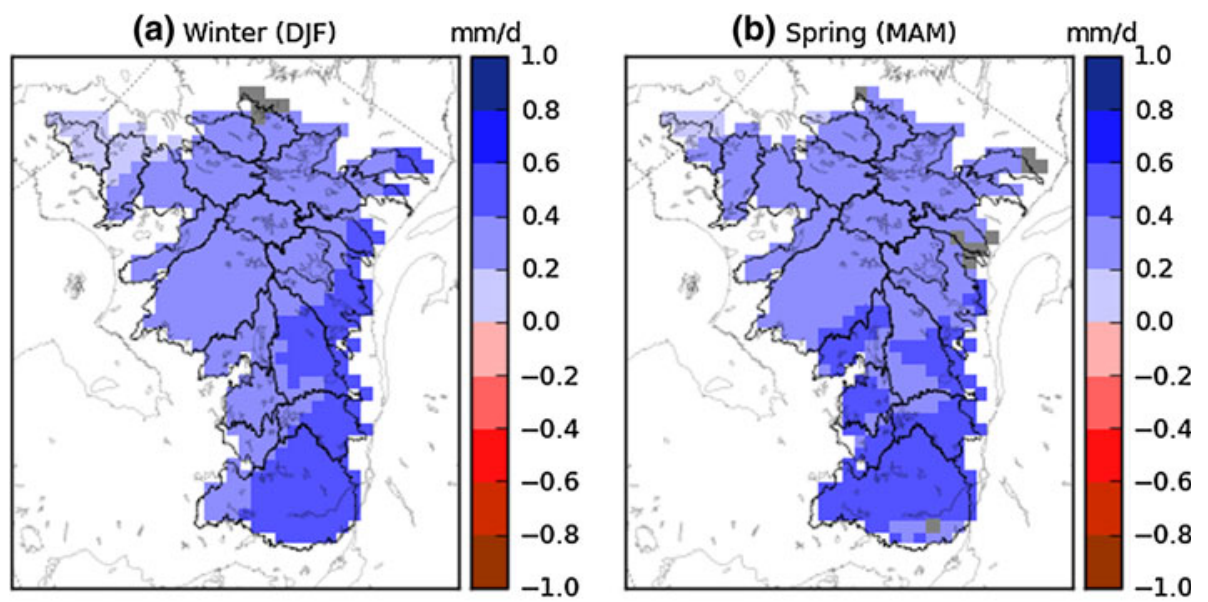

(c) Summer (JJA)

$\mathrm{mm} / \mathrm{d}$

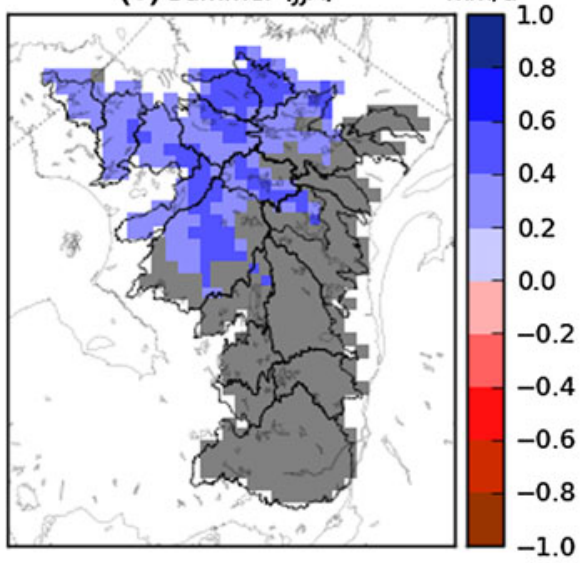

(d) Fall (SON)

$\mathrm{mm} / \mathrm{d}$

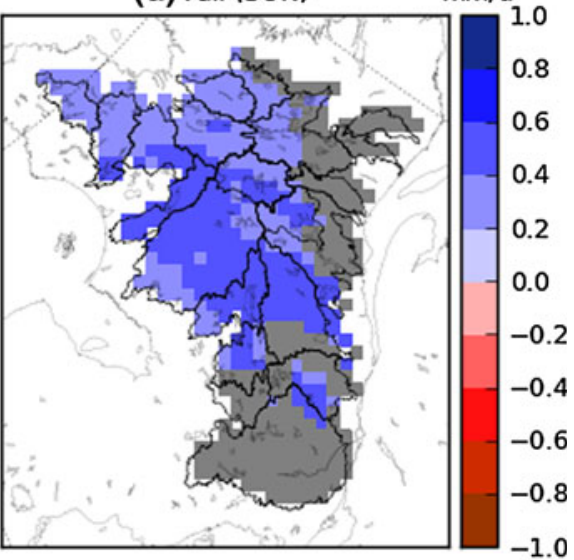

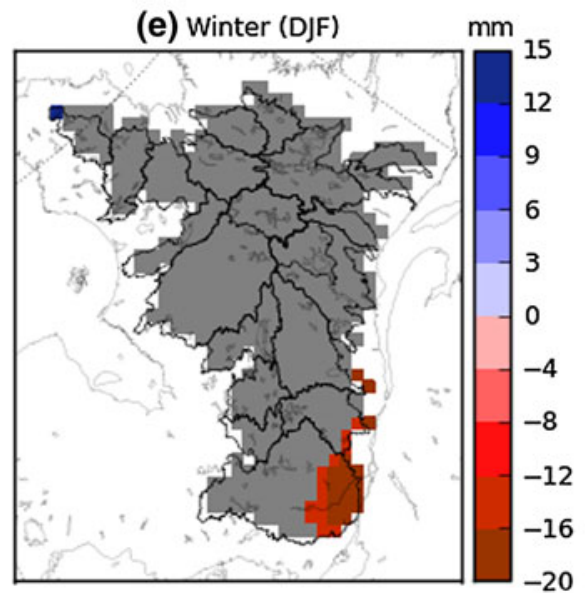

melting processes and their relative timings. Compared to low-flow return levels, considerable variability in spring high flows also could explain the lack of significant changes in high-flow return levels. All the five members suggest significant changes to low-flow return levels for the entire region except few grid cells located mainly in the RDO and northern watersheds where the number of members suggesting significant changes varies between 1 and 4. Because of the good agreement between individual members, ensemble-averaged changes are also found statistically significant at the $5 \%$ level for the entire study domain, except a few grid cells located in the RDO watershed (Figs. 12f, 13f).

The CV plots for projected changes to high- and lowflow return levels shown in Fig. 14 indicate that greater confidence can be attributed to the changes in low-flow 
Fig. 8 Ensemble averaged normalized frequency of occurrence of 1-day high flow events for current 1970-1999 (left $\mathrm{y}$-axis) and future 2041-2070 (right y-axis) period for northern (top panel), central (middle panel) and southern (bottom panel) watersheds. The numbers correspond to watershed indices given in Table 1. Inset shows changes to normalized frequency of occurrence from current to future climate

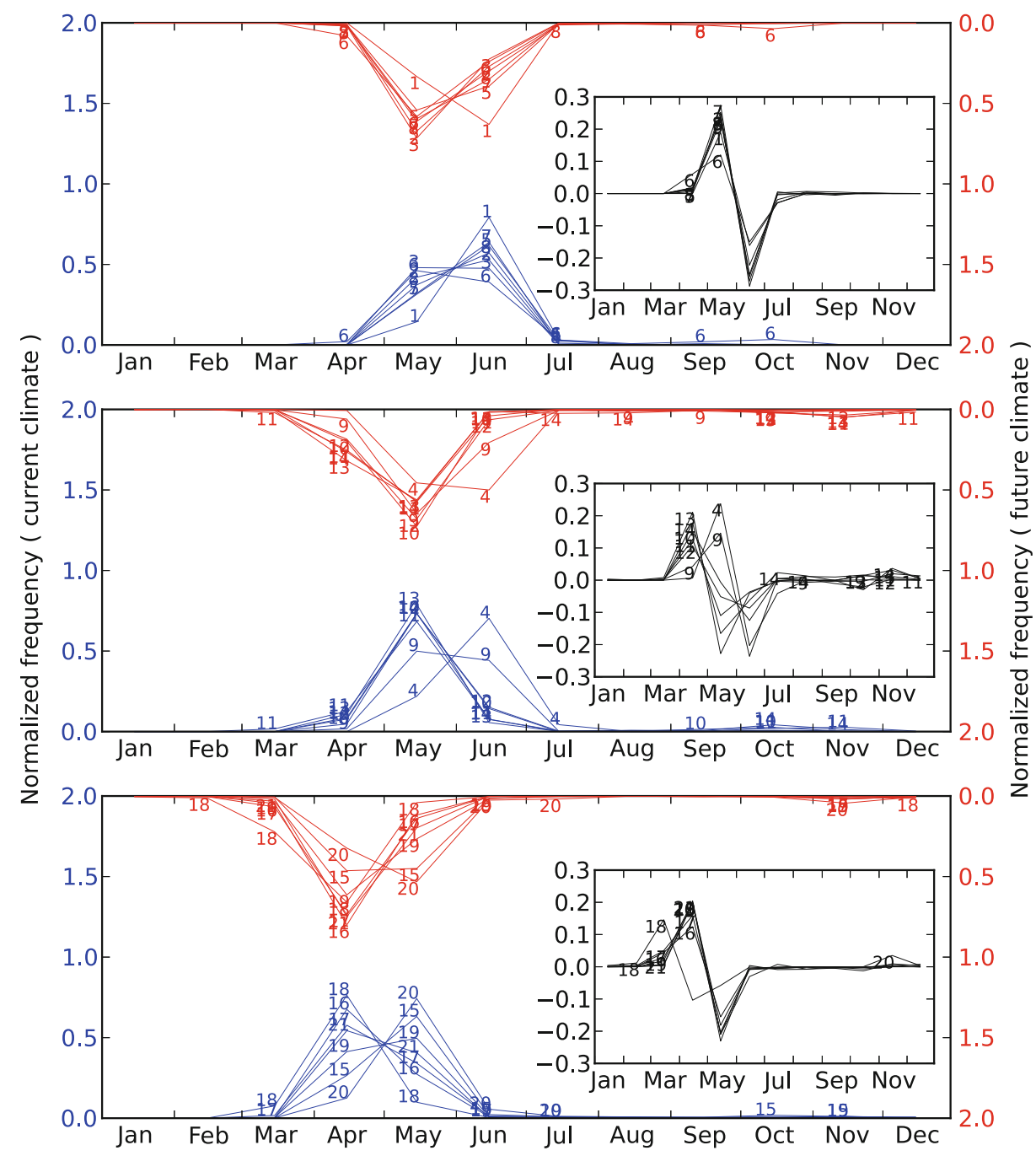

return levels since $\mathrm{CV}$ values are much smaller than 1 over most of the domain. More specifically, in the case of high flows, smaller values of $\mathrm{CV}$ are found for northern (ARN, FEU, MEL, PYR and BAL) watersheds.

\subsection{Projected changes based on merged longer samples}

In order to decrease the uncertainties associated with the small sample size, we tested separately for current and future climates the hypothesis that the samples of mean annual streamflows from the five ensemble members originate from the same distribution using two multiple comparison tests discussed in the methodology, i.e. the Kruskal-Wallis test and the ranksum test combined with the FDR approach. The same analysis is performed separately for the samples of high- and low-flow extremes. The results of both tests were similar and therefore only those corresponding to the former test are shown in Fig. 15. The $p$ values of the Kruskal-Wallis test plotted in Fig. 15a suggest that the null hypothesis that the five samples of mean annual flows originate from the same distribution cannot be rejected at the $5 \%$ level for majority of the grid cells. The same is the case for low- and high-flow samples. However, compared to the case of mean annual and low flows, there are more grid cells, located mainly in the central and southern parts of the study domain, where the null hypothesis does not seem to hold for high flows. Since for majority of the grid cells the null hypothesis does seem to hold for both current and future climates, projected changes in mean annual and seasonal flows and return levels of low- and high-flows are assessed using longer samples consisting of 150 values obtained by merging the 5 current simulations and similarly the 5 future simulations for each grid-cell. The results of this analysis are summarized below as for the first method.

The projected changes to mean annual and seasonal flows are shown in Fig. 16. The changes to mean annual flows are found significant at the $5 \%$ level for the entire 
Fig. 9 Same as in Fig. 8 but for low flow events

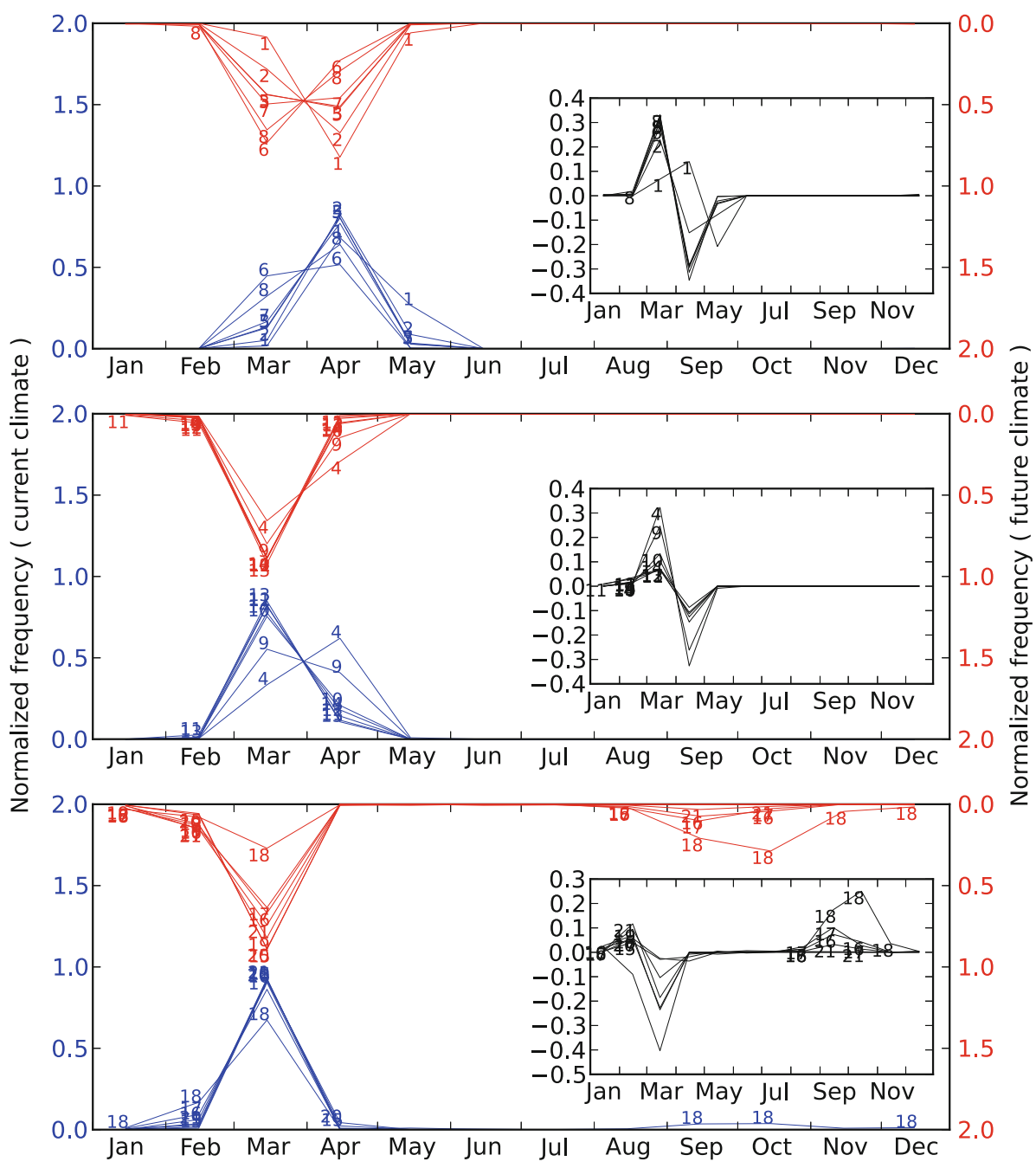

study domain, except few grid cells located in southernmost parts of the RDO watershed. Spatial pattern of changes to winter flows is very similar to that of the mean annual flows. Compared to the results for the ensemble mean shown in Fig. 5, significant reduction to flows is more wide spread over the southern watersheds in fall as well as in summer. For spring flows, the smaller positive increases for southern parts of the domain, which were not significant earlier, are now found significant at the $5 \%$ level. Similar patterns of spatial changes to annual and seasonal flows were noticed using the $t$ test.

Spatial patterns of projected changes to selected return levels of high and low flows are shown in Fig. 17. Compared to the results shown in Figs. 10f and 11f, there is a larger number of grid cells where the increases to 10- and 30 -year return levels of high flows are now found significant at the $5 \%$ level. This is clearly the case for the northern watersheds: ARN, FEU, MEL, PYR, BAL and GRB. The increases to 2- and 5-year low-flow return levels are significant all over the study domain. Thus, this approach based on longer samples results in an increase in the number of grid cells with significant changes.

These results strongly suggest that the uncertainties due to small sample sizes could be substantial. Therefore, longer simulations appear to be much valuable to derive a robust climate change signal, not only for extreme flows but also for annual and seasonal means. In our case, the increase of the sample size from 30 to 150 seems appropriate to discriminate the climate-change signal from the noise due to smaller sample size, in addition to other factors.

\section{Discussion and conclusions}

According to the 4th Assessment Report of the IPCC (2007), increase in precipitation for some regions around the world, including the northern mid- to high-latitudes, is 
Fig. 10 a-e Projected changes (in \%) to10-year return levels of 1-day high flows derived from five future and current period simulation pairs (F1-C1, F2-C2, .., F5-C5). f Ensemble averaged changes to 10 -year return levels of high flows. Grid cells where the changes are not significant at the $5 \%$ significance level are shown in grey (a)

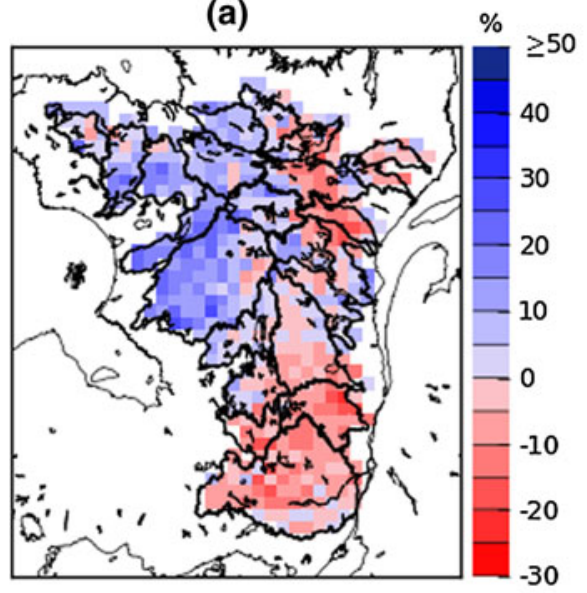

(c)

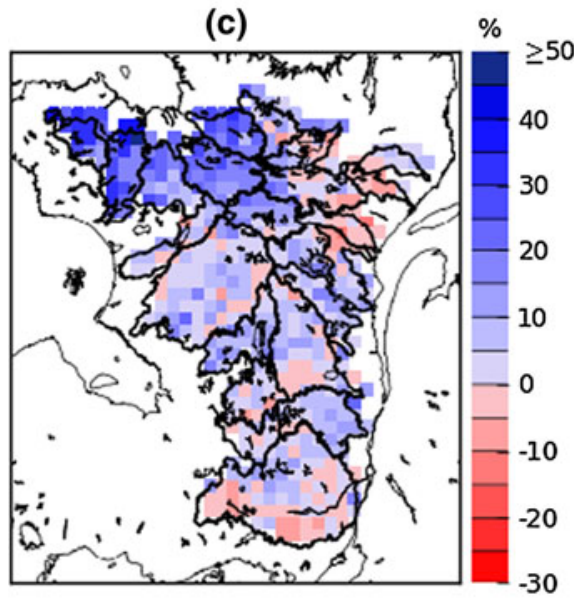

(e)

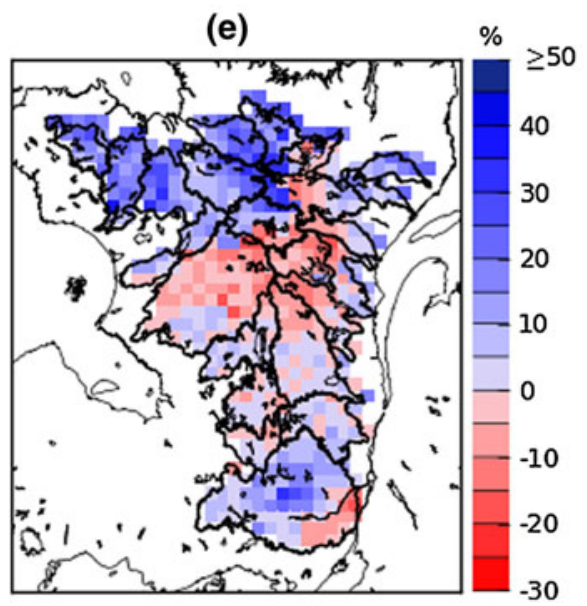

(b)

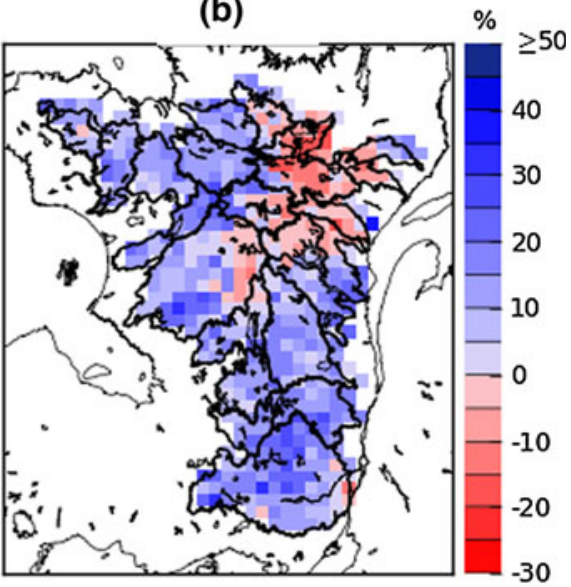

(d)

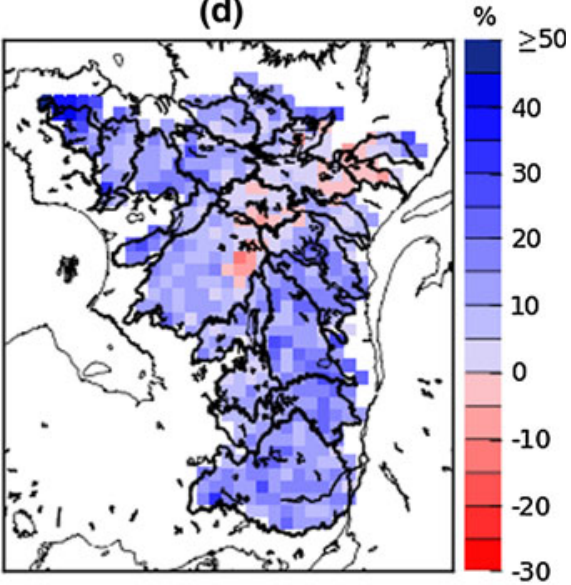

(f)

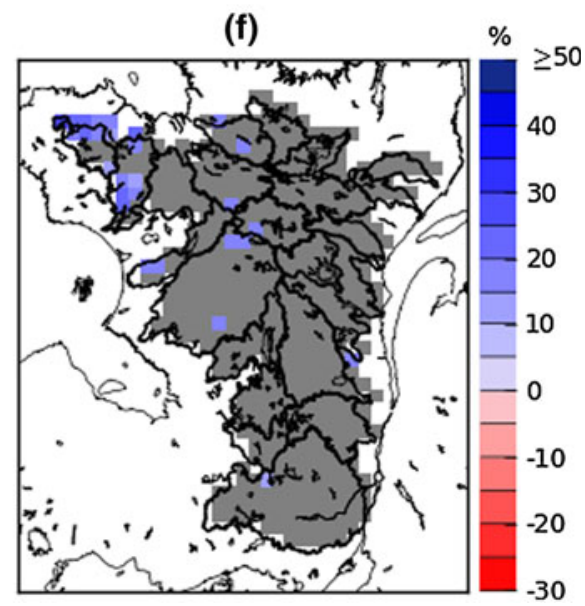

expected in future climate. This can directly influence characteristics of streamflows. The northeast Canadian watersheds considered in this study are particularly vulnerable to changes in streamflow patterns since $96 \%$ of consumed electricity in the region is hydro-based. In the northern part of Quebec, which is also the focus of future development, storage power stations represent $95 \%$ of installed capacity, while run-of-river power stations accounts for $95 \%$ of the installed capacity in the southern parts of Quebec. Therefore, assessment of projected changes to streamflow characteristics is important to aid decision-making and identification of appropriate measures for adaptation of hydroelectric storage reservoirs in this economically important region of Canada. 
Fig. 11 Same as in Fig. 10 but for 30-year return levels of high flows (a)

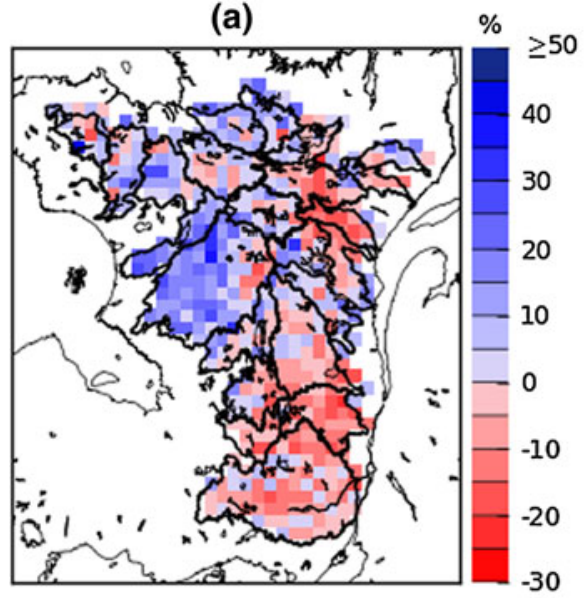

(c)

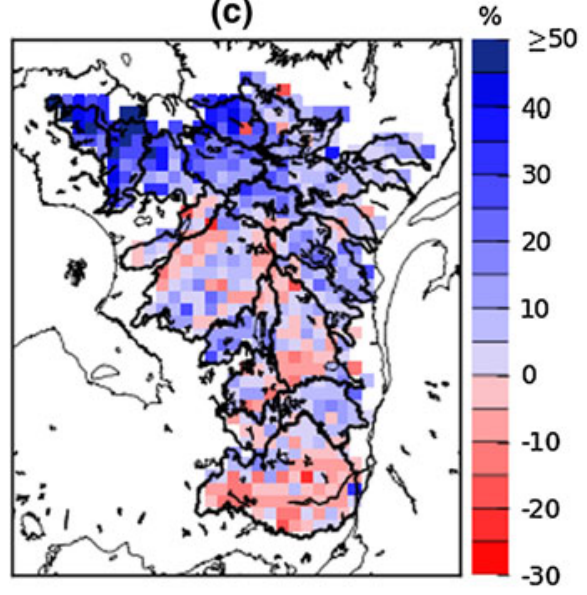

(e)

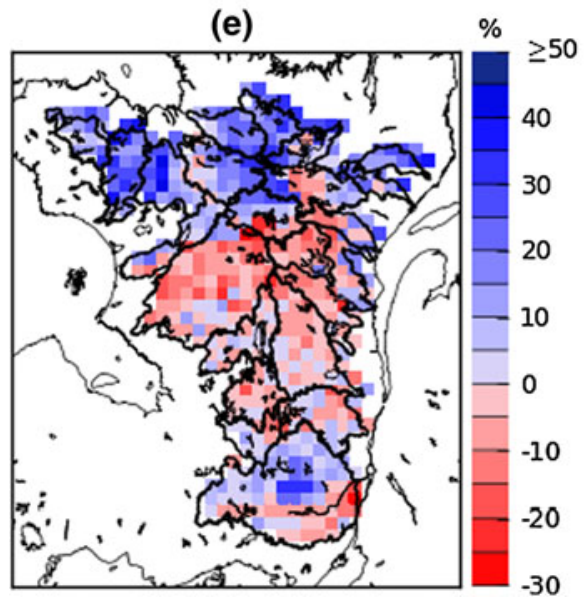

(b)

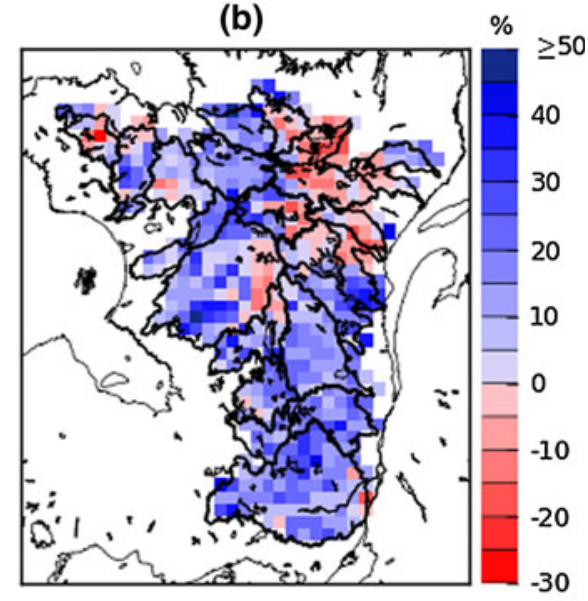

(d)

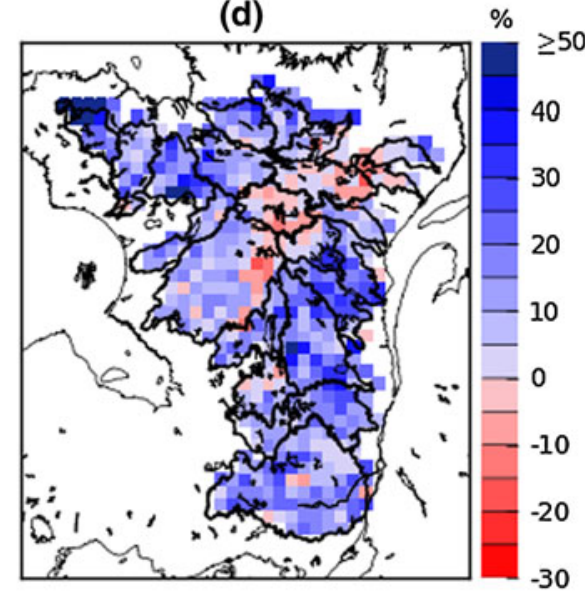

(f)

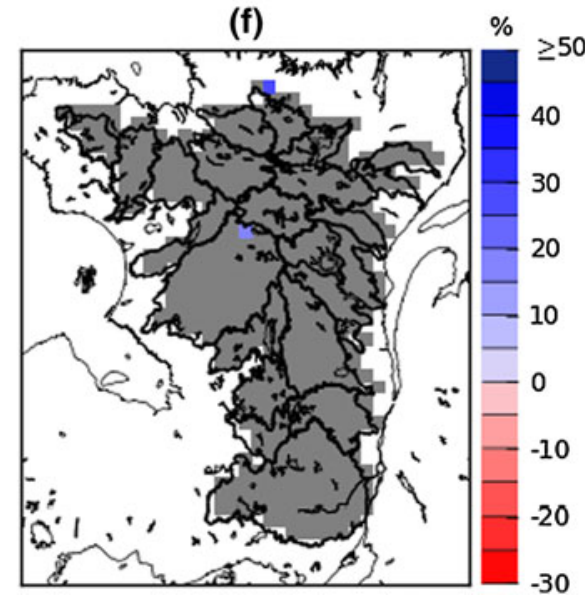

This paper presents an evaluation of the CRCM-simulated streamflow characteristics (mean annual and seasonal streamflows and selected return levels of high- and lowflow events) over 21 Northeastern Canadian watersheds. High flows, defined as 1-day maximum flows occurring over the March to July period (commonly known as spring floods) and low flows, defined as 15-day minimum flows occurring over the January to May period, are derived from daily streamflow values which in turn are obtained by routing CRCM-generated runoff using a modified WATROUTE scheme (Soulis et al. 2000; Poitras et al. 2011). Projected changes to streamflow characteristics are derived using an ensemble of ten CRCM simulations, five corresponding to current $1970-1999$ period and five to the 
Fig. 12 a-e Projected changes (in \%) to 2-year return levels of 15-day low flows derived from five future and current period simulation pairs $(\mathrm{F} 1-\mathrm{C} 1$, F2-C2, .., F5-C5). f Ensemble averaged changes to 2-year return levels of low flows. Grid cells where the changes are not significant at the $5 \%$ significance level are shown in grey
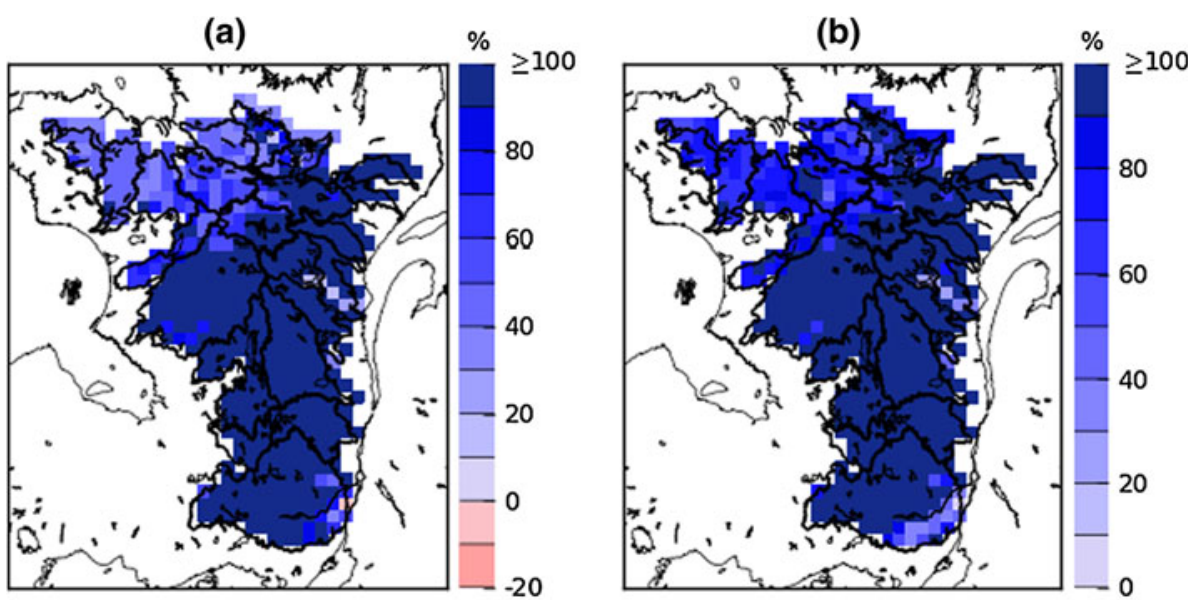

(c)

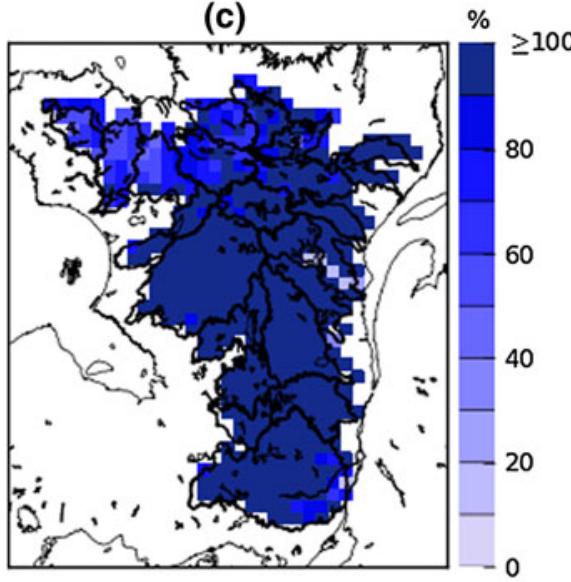

(e)

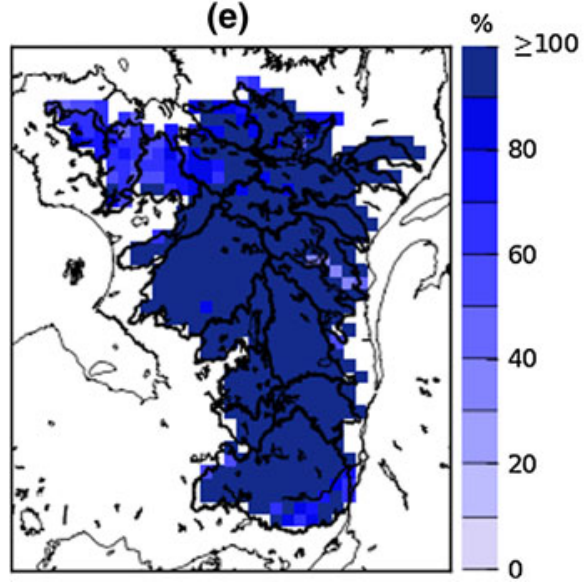

(d)

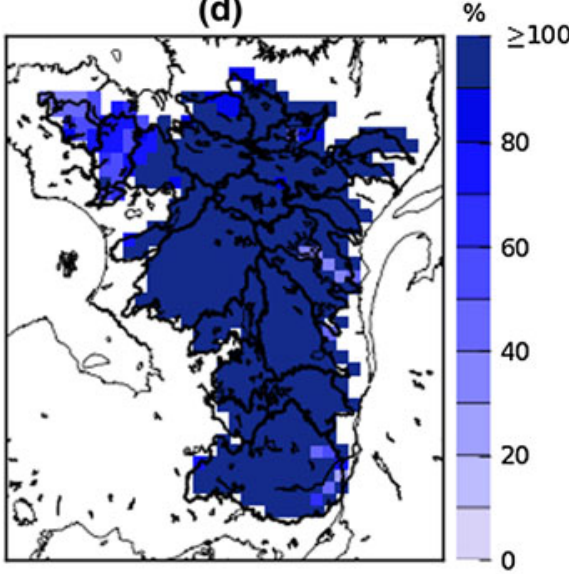

(f)

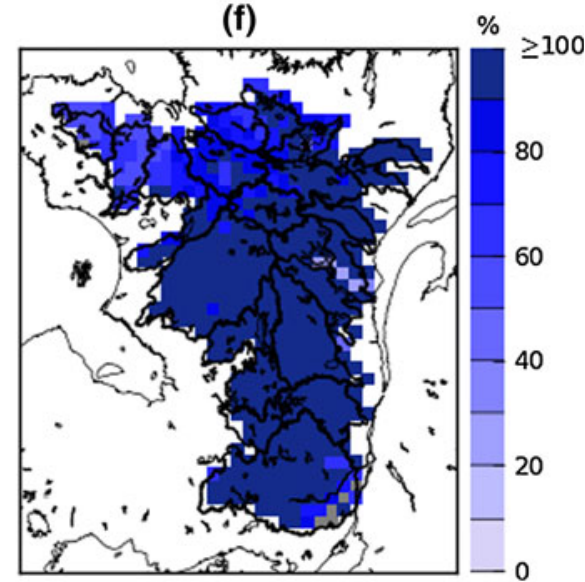

future 2041-2070 period under the A2 SRES scenario. Two methods, one based on the ensemble-averaging approach and the other based on merged samples of five current and five future simulations following multiple comparison tests, are used to develop projected changes. From the set of analyses performed in this study, the following conclusions were drawn.
A comparison of mean daily streamflow hydrographs derived from the CRCM simulation when it was driven by ERA40 data (Uppala et al. 2005) at its boundaries and those derived from observed data at selected stations shows that the shapes of the hydrographs agree overall. However, some differences are noted both in the magnitude and timing of peak flows. Overall, the model simulates 
Fig. 13 Same as in Fig. 12 but for 5-year return levels of low flows
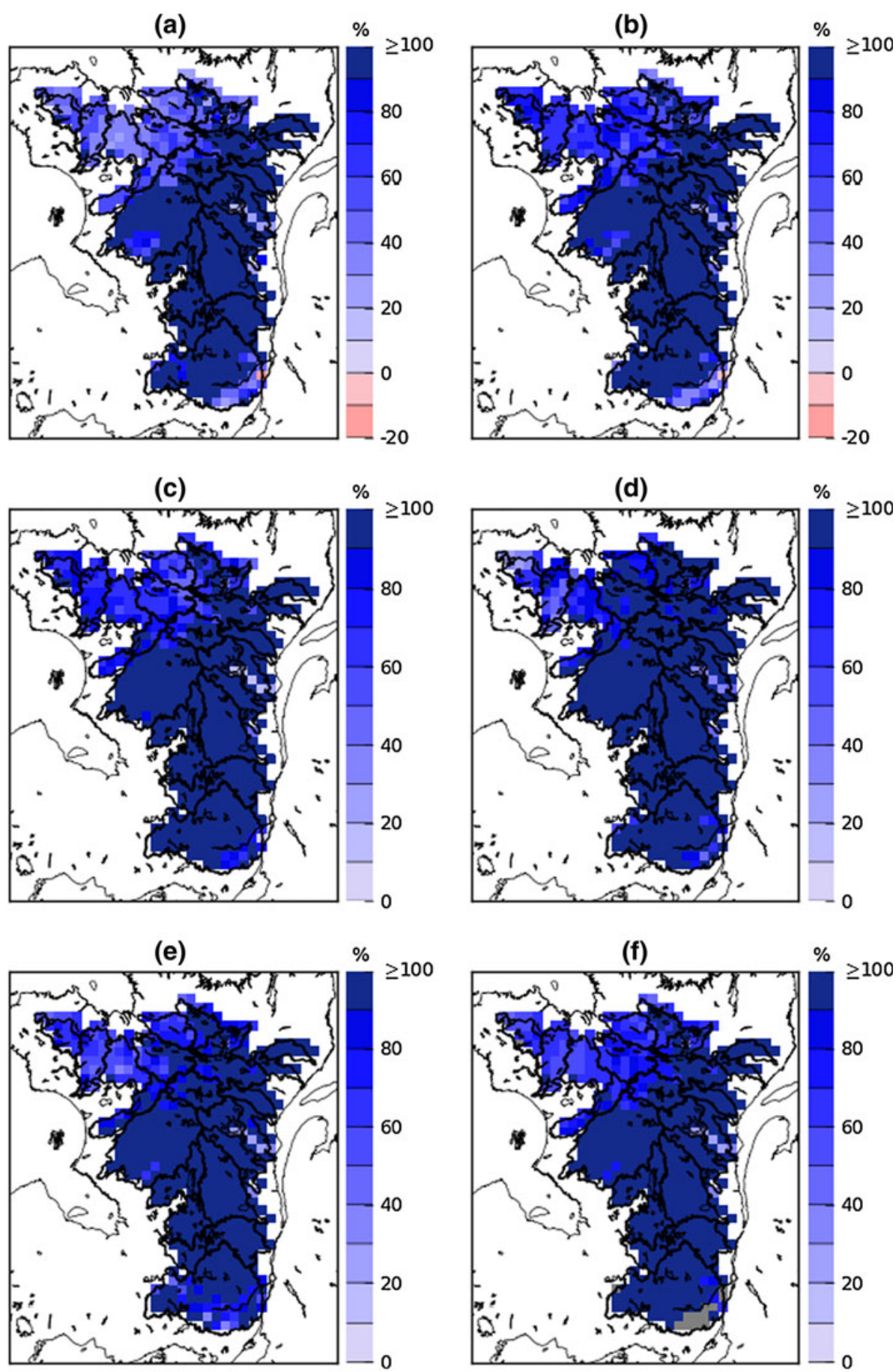

reasonably well the magnitude of high-flow events, but it performs poorly in simulating magnitude of low-flow events. The low-flow discrepancies are attributed primarily to the coarse resolution of the soil dataset and the drainage criterion used in the model.

Future climate change projections suggest significant increases in mean annual river flows with maximum changes occurring over the northern part of the study domain. Significant decreases in fall seasonal flows are projected for southern parts of the studied region and almost same is the case for summer seasonal flows. Changes to winter flows follow closely the pattern of mean annual flows. Though increases in spring seasonal flows are also significant over most part of the domain, they are more wide spread for northern compared to southern watersheds. 
Fig. 14 Coefficient of variation (ratio of standard deviation to the mean absolute value based on the five ensemble members) of projected changes to selected return levels of high and low flows

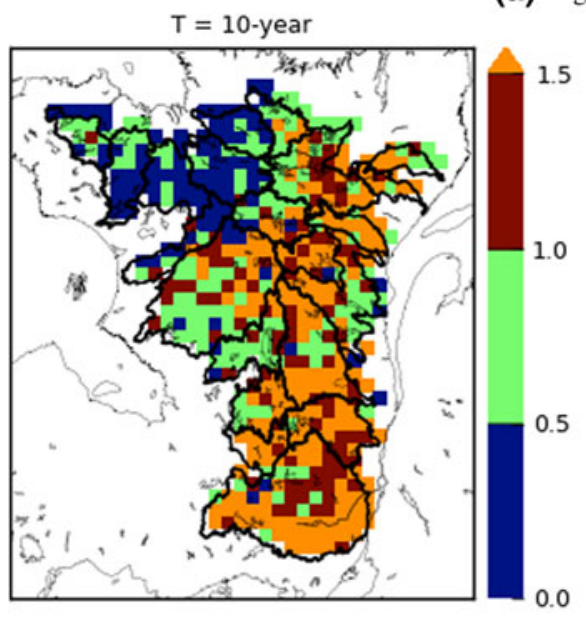

(a) High flow

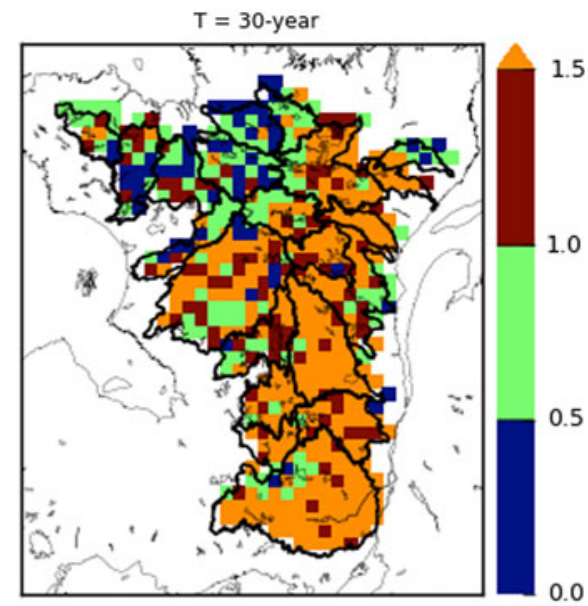

(b) Low flow
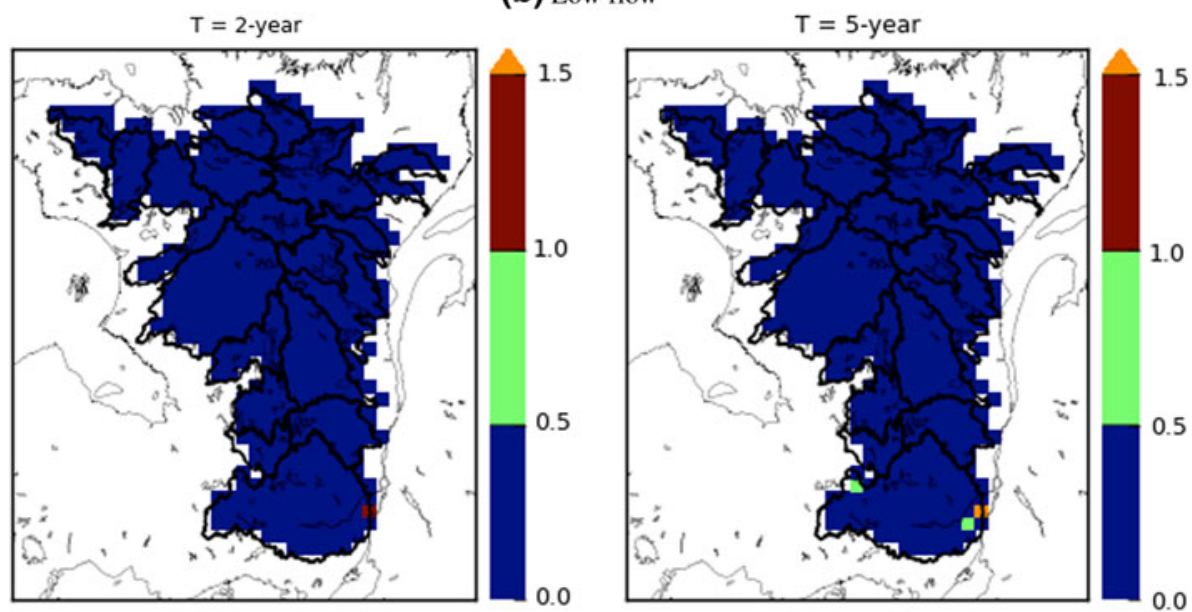

The magnitude of low-flow extremes is projected to increase significantly nearly for all watersheds, though the change in absolute terms is small. Compared to the case of low-flow extremes where the changes are mostly significant, changes to high-flow extremes are not generally found significant based on the ensemble-averaged approach. However, when small sample uncertainties are addressed by using merged longer samples, a number of grid cells with significant increases in high-flow return levels emerged for northern watersheds: ARN, FEU, MEL, PYR, BAL and GRB. In general, the return levels corresponding to short return periods are found significant more often compared to those corresponding to longer return periods.

From the analysis performed in this study, it can be concluded that larger number of ensemble members and/or longer simulations seems to be indispensable for deriving a robust climate-change signal as was concluded by Kendon et al. (2008), from their analysis of a 3-member Hadley Centre RCM. In the use of a parametric approach for analysis of changes to return levels of extremes, as is the case of the current study, longer simulation periods could also decrease the uncertainties associated with the estimation of extreme value distribution parameters. In this study, the increase of the sample size from 30 to 150 values seems appropriate to discriminate the climate change signal from the noise, since the study is based on a single RCM.

To improve the confidence in projected changes to streamflows, model improvements are necessary. The land surface scheme in the CRCM simulations considered in this study used a 3-layer configuration, with a very thick third layer. To improve further the realism of the simulated soil thermal and hydrologic cycle, and therefore the simulated streamflows, it is preferable to have higher resolution for soil layers. Another aspect that can be further improved is the frozen soil formulation in the model. For example, Niu and Yang (2006), obtained important improvements with simulated streamflows for cold regions, particularly with respect to the timing and magnitude of peak streamflow, in their study using the Community Land 
Fig. $15 p$ values of the

Kruskal-Wallis test for a mean annual flows, b 15-day low flows, and c 1-day high flows for current (left column) and future (right column) climates
Current climate

(a) Mean flow

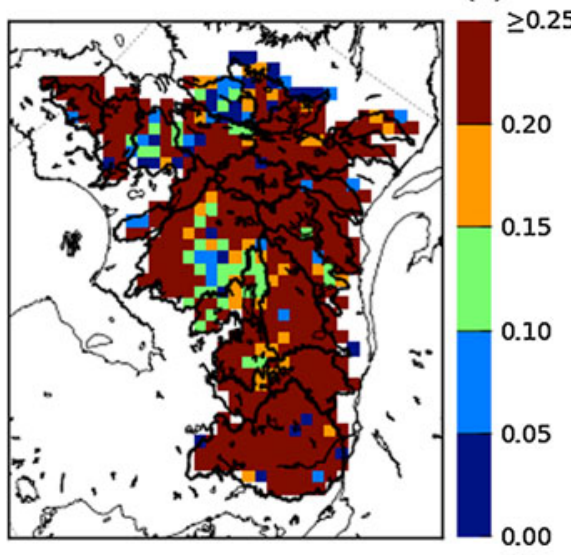

Future climate

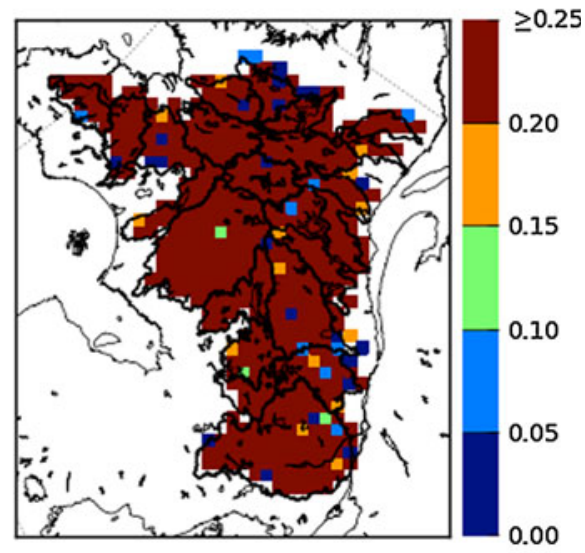

(b) Low flow
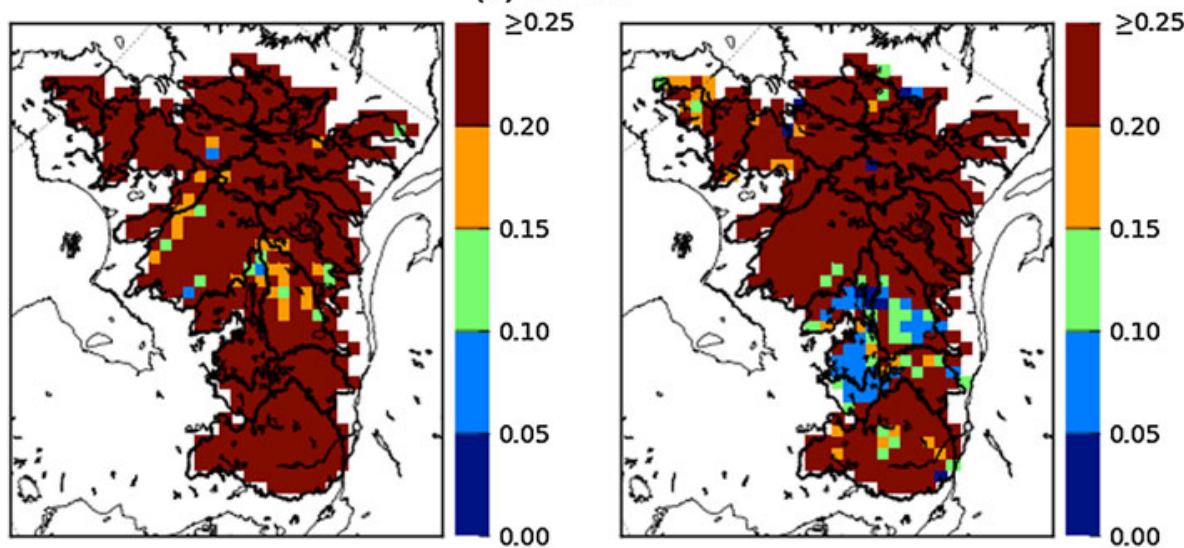

(c) High flow
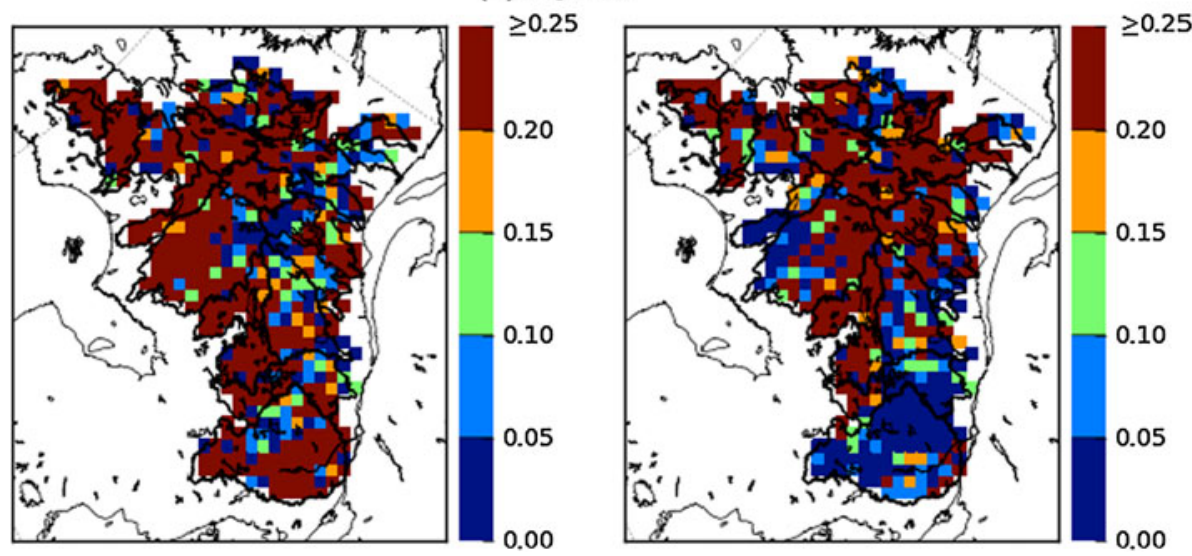

Model (CLM), by introducing supercooled soil water by implementing a freezing-point depression equation and by relaxing the dependence of the hydraulic properties on soil ice content by incorporating the concept of fractional impermeable area, which enhanced the permeability of frozen ground. In addition, Yuan and Liang (2011) in their study using a Conjunctive Surface-Subsurface Process model, with an explicit treatment of surface-subsurface flow interaction with the bedrock treated as an unconfined aquifer, showed improved simulation of seasonal-interannual runoff and streamflow variations and extreme events. It is expected that similar improvements to the CRCM could further improve the quality of the simulated streamflows. 
Fig. 16 Projected changes (in

$\%)$ to mean a annual and b-e seasonal streamflows. Grid cells where the changes are not significant at the $5 \%$ significance level are shown in grey
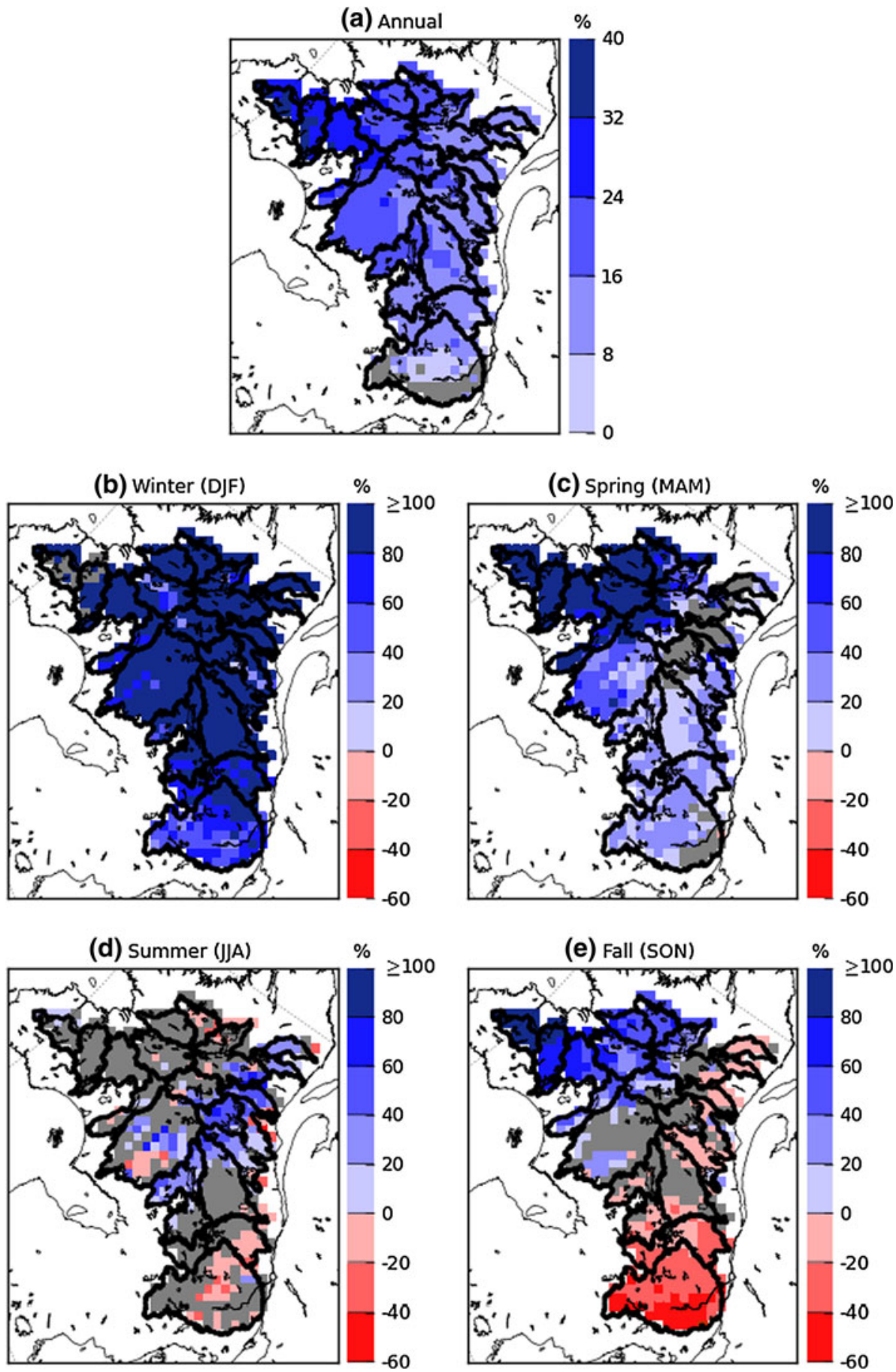

Since one of the main aims of the current article had been to demonstrate the need for longer simulations by considering two approaches, which included merging of samples from the same RCM, we have not considered multi-RCM ensembles in this study. However, future analysis will take into account multi-RCM ensembles, driven by multi-GCMs, to quantify various sources of uncertainties such as structural uncertainty, and those associated with the use of different GCMs as the driving data at the lateral boundaries using the NARCCAP simulations (Mearns et al. 2009). Such assessments are crucial to enable a risk-based approach to decision making (Kay et al. 2009). There is also a need for high-resolution simulations of the order of at least $10 \mathrm{~km}$ to better capture the surface heterogeneity and thus to better simulate streamflows to provide information required for many impact and 
Fig. 17 Projected changes (in $\%$ ) to 10 - and 30-year return levels of high flows (left column) and 2- and 5-year return levels of low flows (right column) derived using longer samples (consisting of 150 values) for each grid-cell both for current and future climates. Grid cells where the changes are not significant at the $5 \%$ significance level are shown in grey
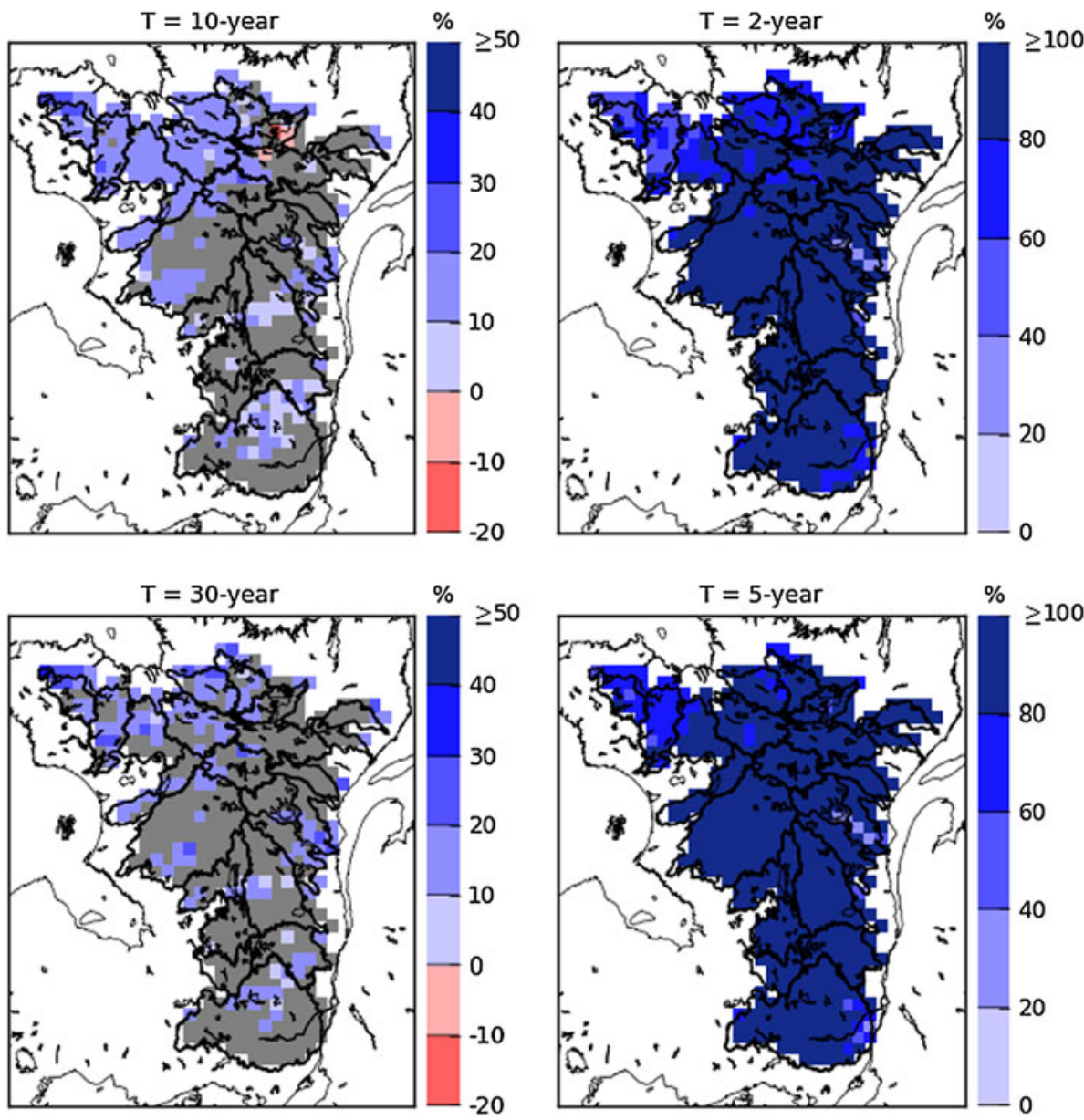

adaptation studies. It is expected that such simulations will be available in the near future.

Acknowledgments This research was carried out within a Collaborative Research and Development (CRD) project funded by the Natural Sciences and Engineering Research Council (NSERC) of Canada, with Hydro-Quebec/Ouranos as industrial partner. The authors would like to thank the Climate Simulations Team of Ouranos Consortium for providing the CRCM runoff data used in the study and two anonymous referees and the Editor Prof. E. K. Schneider for their helpful comments.

Open Access This article is distributed under the terms of the Creative Commons Attribution License which permits any use, distribution, and reproduction in any medium, provided the original author(s) and the source are credited.

\section{References}

Ailliot P, Thompson C, Thomson P (2011) Mixed methods for fitting the GEV distribution. Water Resour Res 47(W05551). doi: 10.1029/2010wr009417

Arnell NW (2011) Uncertainty in the relationship between climate forcing and hydrological response in UK catchments. Hydrol Earth Syst Sci 15:897-912
Bechtold P, Bazile E, Guichard F, Mascart P, Richard E (2001) A mass-flux convection scheme for regional and global models. Q J R Meteorol Soc 127(573):869-886

Benjamini Y, Hochberg Y (1995) Controlling the false discovery rate- a practical and powerful approach to multiple testing. J R Stat Soc B Met 57(1):289-300

Berrisford P, Dee D, Fielding K, Fuentes M, Kallberg P, Kobayashi S, Uppala S (2009) The ERA-Interim Archive. ERA report series. European Centre for Medium-Range Weather Forecasts

Brasnett B (1999) A global analysis of snow depth for numerical weather prediction. J Appl Meteorol 38(6):726-740

Brown RD, Brasnett B, Robinson D (2003) Gridded North American monthly snow depth and snow water equivalent for GCM evaluation. Atmos Ocean 41(1):1-14

Coles S (2001) An introduction to statistical modeling of extreme values. Springer, London

Dadson SJ, Bell VA, Jones RG (2011) Evaluation of a grid-based river flow model configured for use in a regional climate model. J Hydrol 411(3-4):238-250. doi:10.1016/J.Jhydrol.2011.10.002

Davies HC (1976) A laterul boundary formulation for multi-level prediction models. Q J R Meteorol Soc 102(432):405-418

de-Elia R, Cote H (2010) Climate and climate change sensitivity to model configuration in the Canadian RCM over North America. Meteorol Z 19(4):325-339

de-Elia R, Caya D, Cote H, Frigon A, Biner S, Giguere M, Paquin D, Harvey R, Plummer D (2008) Evaluation of uncertainties in the CRCM-simulated North American climate. Clim Dyn 30(2-3): 113-132 
Dibike YB, Coulibaly P (2007) Validation of hydrological models for climate scenario simulation: the case of Saguenay watershed in Quebec. Hydrol Process 21(23):3123-3135

Döll P, Lehner B (2002) Validation of a new global 30-min drainage direction map. J Hydrol 258(1-4):214-231

Efron B, Tibshirani R (1993) An introduction to the bootstrap. Monographs on statistics and applied probability. Chapman \& Hall, New York

Frigon A, Music B, Slivitzky M (2010) Sensitivity of runoff and projected changes in runoff over Quebec to the update interval of lateral boundary conditions in the Canadian RCM. Meteorol Z 19(4):399

Gal-Chen T, Somerville RCJ (1975) On the use of a coordinate transformation for the solution of the Navier-Stokes equations. J Comput Phys 17(2):209-228

Graham LP, Andreasson J, Carlsson B (2007a) Assessing climate change impacts on hydrology from an ensemble of regional climate models, model scales and linking methods-a case study on the Lule River basin. Clim Change 81:293-307

Graham LP, Hagemann S, Jaun S, Beniston M (2007b) On interpreting hydrological change from regional climate models. Clim Change 81:97-122

GREHYS (1996) Inter-comparison of regional flood frequency procedures for Canadian rivers. J Hydrol 186(1-4):85-103

Hall MJ, van den Boogaard HFP, Fernando RC, Mynett AE (2004) The construction of confidence intervals for frequency analysis using resampling techniques. Hydrol Earth Syst Sci 8:235-246

Held IM, Soden BJ (2006) Robust responses of the hydrological cycle to global warming. J Clim 19(21):5686-5699

Hosking JRM (1990) L-moments: analysis and estimation of distributions using linear combinations of order statistics. J R Stat Soc B 52(1):105-124

Hosking JRM, Wallis JR, Wood EF (1985) Estimation of the generalized extreme-value distribution by the method of probability-weighted moments. Technometrics 27(3):251-261

IPCC (2001) Climate change 2001: the scientific basis. In: Contribution of Working Group I to the Third Assessment Report of the Intergovernmental Panel on Climate Change. Cambridge, United Kingdom and New York, NY, USA

IPCC (2007) Climate change 2007: the physical science basis. Contribution of Working Group I to the Fourth Assessment Report of the Intergovernmental Panel on Climate Change. Cambridge, United Kingdom and New York, NY, USA

Jha M, Pan ZT, Takle ES, Gu R (2004) Impacts of climate change on streamflow in the Upper Mississippi River Basin: a regional climate model perspective. J Geophys Res-Atmos 109(D09105)

Kay AL, Jones RG, Reynard NS (2006a) RCM rainfall for UK flood frequency estimation. II. Climate change results. J Hydrol 318(1-4):163-172

Kay AL, Reynard NS, Jones RG (2006b) RCM rainfall for UK flood frequency estimation. I. Method and validation. J Hydrol 318(1-4):151-162

Kay AL, Davies HN, Bell VA, Jones RG (2009) Comparison of uncertainty sources for climate change impacts: flood frequency in England. Clim Change 92:41-63

Kendon EJ, Rowell DP, Jones RG, Buonomo E (2008) Robustness of future changes in local precipitation extremes. J Clim 21:4280-4297

Khaliq MN, Ouarda TBMJ, Gachon P, Sushama L (2008) Temporal evolution of low-flow regimes in Canadian rivers. Water Resour Res 44(W08436). doi:10.1029/2007wr00613

Khaliq MN, Ouarda TBMJ, Gachon P, Sushama L, St-Hilaire A (2009) Identification of hydrological trends in the presence of serial and cross correlations: a review of selected methods and their application to annual flow regimes of Canadian rivers. J Hydrol 368(1-4):117-130
Lehner B, Verdin K, Jarvis A (2008) New global hydrography derived from spaceborne elevation data. Eos Trans AGU 89(10):93

Lucas-Picher P, Arora VK, Caya D, Laprise R (2003) Implementation of a large-scale variable velocity river flow routing algorithm in the Canadian Regional Climate Model (CRCM). Atmos Ocean 41(2):139-153

Martins E, Stedinger J (2000) Generalized maximum-likelihood generalized extreme-value quantile estimators for hydrologic data. Water Resour Res 36(3):737-744

May W (2008) Potential future changes in the characteristics of daily precipitation in Europe simulated by the HIRHAM regional climate model. Clim Dyn 30(6):581-603

Mearns LO, Gutowski WJ, Jones R, Leung LY, McGinnis S, Nunes AMB, Qian Y (2009) A regional climate change assessment program for North America. Eos Trans Am Geophys Union 90:311-312

Minville M, Brissette F, Leconte R (2008) Uncertainty of the impact of climate change on the hydrology of a nordic watershed. J Hydrol 358(1-2):70-83

Minville M, Brissette F, Krau S, Leconte R (2009) Adaptation to climate change in the management of a Canadian waterresources system exploited for hydropower. Water Resour Manag 23(14):2965-2986

Mitchell TD, Jones PD (2005) An improved method of constructing a database of monthly climate observations and associated highresolution grids. Int J Climatol 25(6):693-712. doi:10.1002/Joc. 1181

Mladjic B, Sushama L, Khaliq MN, Laprise R, Caya D, Roy R (2011) Canadian RCM projected changes to extreme precipitation characteristics over Canada. J Clim 24:2565-2584

Nash JE, Sutcliffe JV (1970) River flow forecasting through conceptual models. Part I: a discussion of principles. J Hydrol 10:282-290

Niu G-Y, Yang Z-L (2006) Effects of frozen soil on snowmelt runoff and soil water storage at a continental scale. J Hydrometeorol 7:937-952

Poitras V, Sushama L, Seglenieks F, Khaliq MN, Soulis E (2011) Projected changes to streamflow characteristics over Western Canada as simulated by the Canadian RCM. J Hydrometeorol 12(6): 1395-1413

Quilbé R, Rousseau AN, Moquet JS, Trinh NB, Dibike Y, Gachon P, Chaumont D (2008) Assessing the effect of climate change on river flow using general circulation models and hydrological modelling - application to the Chaudiere River, Quebec, Canada. Can Water Resour J 33(1):73-93

Rudolf B, Becker A, Schneider U, Meyer-Christoffer A, Ziese M (2010) The new "GPCC Full Data Reanalysis Version 5" providing highquality gridded monthly precipitation data for the global landsurface is public available since December 2010. GPCC Status Report. Global Precipitation Climatology Centre, Germany

Smakhtin VU (2001) Low flow hydrology: a review. J Hydrol 240(3-4):147-186

Soulis ED, Snelgrove KR, Kouwen N, Seglenieks F, Verseghy DL (2000) Towards closing the vertical water balance in Canadian atmospheric models: coupling of the land surface scheme CLASS with the distributed hydrological model WATFLOOD. Atmos Ocean 38(1):251-269

Stedinger JR, Vogel RM, Foufouls-Georgiou E (1993) Frequency analysis of extreme events. In: Handbook of hydrology. McGraw-Hill Book Co., Inc., New York

Sushama L, Laprise R, Caya D, Larocque M, Slivitzky M (2004) On the variable-lag and variable-velocity cell-to-cell routing schemes for climate models. Atmos Ocean 42(4):221-233

Sushama L, Laprise R, Caya D, Frigon A, Slivitzky M (2006) Canadian RCM projected climate-change signal and its sensitivity to model errors. Int J Climatol 26(15):2141-2159 
Uppala SM, Kallberg PW, Simmons AJ, Andrae U, Bechtold VD, Fiorino M, Gibson JK, Haseler J, Hernandez A, Kelly GA, Li X, Onogi K, Saarinen S, Sokka N, Allan RP, Andersson E, Arpe K, Balmaseda MA, Beljaars ACM, Van De Berg L, Bidlot J, Bormann N, Caires S, Chevallier F, Dethof A, Dragosavac M, Fisher M, Fuentes M, Hagemann S, Holm E, Hoskins BJ, Isaksen L, Janssen PAEM, Jenne R, McNally AP, Mahfouf JF, Morcrette JJ, Rayner NA, Saunders RW, Simon P, Sterl A, Trenberth KE, Untch A, Vasiljevic D, Viterbo P, Woollen J (2005) The ERA-40 re-analysis. Q J R Meteorol Soc 131(612):2961-3012

Verseghy DL (1991) Class-a Canadian land surface scheme for Gcms. 1. Soil model. Int J Climatol 11(2):111-133

Verseghy DL (1996) Local climates simulated by two generations of Canadian GCM land surface schemes. Atmos Ocean 34(3): $435-456$
Walpole RE, Myers RH (1985) Probability and statistics for engineers and scientists, 3rd edn. Macmillan, New York

Wood AW, Leung LR, Sridhar V, Lettenmaier DP (2004) Hydrologic implications of dynamical and statistical approaches to downscaling climate model outputs. Clim Change 62(1-3):189-216

Yakimiw E, Robert A (1990) Validation experiments for a nested grid-point regional forecast model: research note. Atmos Ocean 28(4):466-472

Yuan X, Liang X-Z (2011) Evaluation of a conjunctive surfacesubsurface process model (CSSP) over the contiguous United States at regional-local scales. J Hydrometeorol 12:579-599 